The University of San Francisco

USF Scholarship: a digital repository @ Gleeson Library | Geschke Center

\title{
Facets of Work: Enriching the Description, Analysis, Design, and Evaluation of Systems in Organizations
}

Steven Alter

University of San Francisco, alter@usfca.edu

Follow this and additional works at: https://repository.usfca.edu/at

Part of the Business Commons

\section{Recommended Citation}

Alter, Steven: Facets of Work: Enriching the Description, Analysis, Design, and Evaluation of Systems in Organizations, Communications of the Association for Information Systems (forthcoming), In Press.

This Article is brought to you for free and open access by the School of Management at USF Scholarship: a digital repository @ Gleeson Library | Geschke Center. It has been accepted for inclusion in Business Analytics and Information Systems by an authorized administrator of USF Scholarship: a digital repository @ Gleeson Library I Geschke Center. For more information, please contact repository@usfca.edu. 


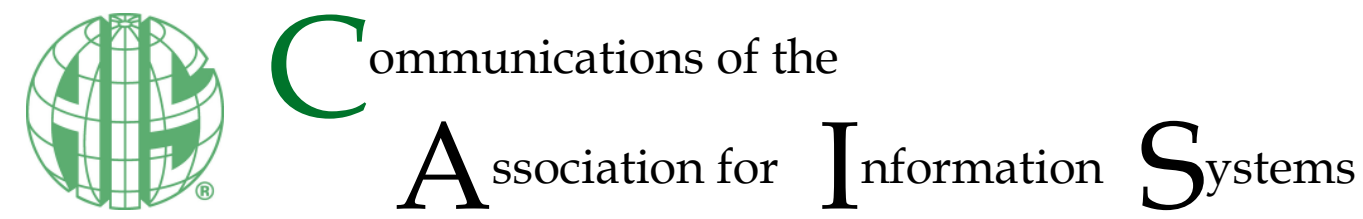

\title{
Accepted Manuscript
}

\section{Facets of Work: Enriching the Description, Analysis, Design, and Evaluation of Systems in Organizations}

\author{
Steven Alter \\ University of San Francisco \\ alter@usfca.edu
}

Please cite this article as: Alter, Steven: Facets of Work: Enriching the Description, Analysis, Design, and Evaluation of Systems in Organizations, Communications of the Association for Information Systems (forthcoming), In Press.

This is a PDF file of an unedited manuscript that has been accepted for publication in the Communications of the Association for Information Systems. We are providing this early version of the manuscript to allow for expedited dissemination to interested readers. The manuscript will undergo copyediting, typesetting, and review of the resulting proof before it is published in its final form. Please note that during the production process errors may be discovered, which could affect the content. All legal disclaimers that apply to the Communications of the Association for Information Systems pertain. For a definitive version of this work, please check for its appearance online at http://aisel.aisnet.org/cais/. 


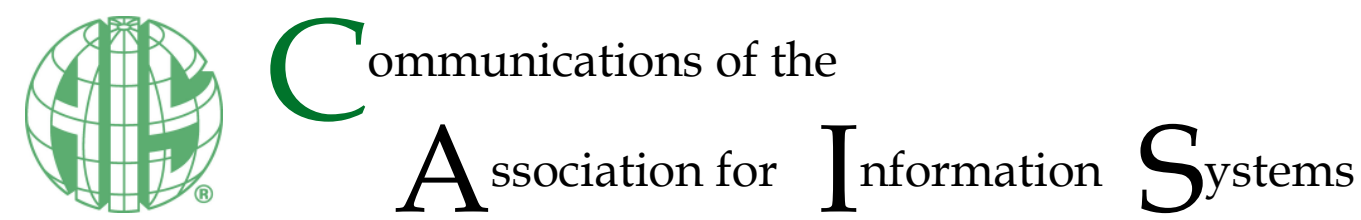

\title{
Facets of Work: Enriching the Description, Analysis, Design, and Evaluation of Systems in Organizations
}

\author{
Steven Alter \\ University of San Francisco \\ alter@usfca.edu
}

\begin{abstract}
:
This conceptual contribution introduces the idea of "facets of work" and explains how it can be applied to challenges in today's IS discipline. The notion of facets of work emerged from earlier attempts to bring more knowledge and richer, more evocative ideas to SA\&D. Focusing on facets of work during initial discussions of requirements could provide guidance without jumping prematurely to details, precision, and formal notation needed for producing testable software. The introduction explains the paper's goal and organization. The next section defines facet of work, identifies underlying assumptions and criteria, and explains how 18 facets of work were identified. Three examples amplify the initial understanding of facets of work by showing how all 18 facets could be applied to specific situations. The next two sections discuss consolidating basic knowledge about facets of work, making that knowledge more accessible, and applying it in SA\&D and in future research. The Appendix explains the disconnected steps that led to the current facets of work. It also presents six lengthy tables that each cover one aspect or another of the 18 facets. Some of those tables form the basis of the tools, methods, and future research mentioned in earlier in the paper.
\end{abstract}

Keywords: Facet, Facets of work, Systems analysis and design, Work system, Artificial intelligence, IS body of knowledge.

[Department statements, if appropriate, will be added by the editors. Teaching cases and panel reports will have a statement, which is also added by the editors.]

[Note: this page has no footnotes.]

This manuscript underwent [editorial/peer] review. It was received $x x / x x / 20 x x$ and was with the authors for $X X$ months for $X X$ revisions. [firstname lastname] served as Associate Editor.] or The Associate Editor chose to remain anonymous.] 


\section{Broadening a Narrow Spectrum of Essentially Mechanical Ideas}

Typical systems analysis and design (SA\&D) textbooks, coursework, and real-world SA\&D practice ignore a great deal of effort and many research publications devoted to relevant research. An important part of that knowledge involves facets of work such as making decisions, communicating, controlling execution, coordinating, and creating value. Those facets of work (a suggestive concept defined later) and many others are mentioned rarely if ever in formal SA\&D methods despite being both relevant and important for describing and analyzing systems, creating requirements, and sanity checking whether proposed system specifications seem likely to address real-world problems effectively.

Highlighting facets of work is an approach for enriching the description, analysis, design, and evaluation of systems in organizations. The idea of facets of work moves beyond the pervasive and rather mechanical metaphor of documenting bounded sets of interrelated steps within processes. It does that by focusing on a broad spectrum of ideas and concerns that are recognized widely but often downplayed or ignored inadvertently in projects that develop software without fully understanding the contexts in which the software will be used.

The idea of facets of work organizes multiple paths for accessing a great deal of research and practical experience. Convenient and well-organized access to relevant chunks of that knowledge might help in creating, evaluating, and improving information systems and other systems in organizations. It also might help researchers describe and analyze organizational routines, IT-enabled systems, applications of AI and machine learning (that may address different facets of work), and other processes and activities in real world settings. Much of that knowledge is from research and experience related to widely studied topics such as decision making, communicating, coordinating, controlling execution, improvising and so on. Each of those topics can be viewed as a focal point for describing and understanding an important aspect of how work is performed, how well it is performed, and why obstacles occur that reduce efficiency and effectiveness. Discrete chunks of knowledge related to facets of work could be built into comparatively simple tools and methods that could facilitate access to that knowledge, thereby encouraging a richer perspective on work activities that entails much more than typical process-oriented documentation of steps triggered by other steps or by specific conditions.

Background. The desirability of incorporating something like facets of work into SA\&D became apparent during two decades of teaching introductory IS courses, mostly for employed MBA and Executive MBA students (and after customer interactions years earlier in a start-up software firm). One of the main student deliverables for most of those courses was a management briefing suggesting how to improve a problematic IT-enabled system in an organization that employed a member of a small student team or a student working individually. That assignment used various versions of a work system analysis template that evolved through ongoing efforts to improve upon previous versions. The template seemed to work well in focusing the attention of MBA and EMBA students on the business issue of improving IT-enabled work systems, rather than on IT per se. Most students seemed to find the exercise beneficial and most of the management briefings seemed satisfactory relative to the limited amount of time that was available. Eventually, over 700 management briefings were produced, mostly in the United States, (e.g., Truex et al., 2010, 2011), but also in China, Germany, India, and Vietnam.

Those assignments generally met their main educational goals but many of the recommendations seemed mundane, e.g., collect data that is not being collected or train work system participants who have not received adequate training. That observation led to wondering whether an appropriately packaged set of system-related metaphors might help early career business professionals produce more interesting or insightful recommendations. Several attempts to pursue that idea (mentioned later) ran into roadblocks due to inadequate framing of the problem. Recent research (also mentioned later) led to insights that eventually generated the idea of facets of work as the core of an approach for stimulating richer views of IT-enabled systems in organizations.

Goal and organization. This paper is a conceptual contribution that explains the idea of facets of work and shows how that idea might be useful. That idea was developed as an extension of work system theory (Alter, 2013b) but can be used totally independent of WST, e.g., in agile development, in describing applications of $\mathrm{Al}$, and in other settings. Accordingly, Appendix 1 will mention WST briefly to establish part of the research context, but the body of the paper does not rely on WST for explaining the idea of facets of work.

This paper is organized in an unusual way because: 
- The idea of "facets of work" is suggestive but certainly is not part of the typical IS lexicon. Also, it is distant from the way most members of the IS community think and teach about SA\&D and is not linked directly to the variables typically included in research trying to explain causes of frequent difficulties in system development.

- Development of the idea addressed an aspect of SA\&D that is rarely viewed as a major problem. Rather, it was pursued based on a personal belief about possible benefits of searching for a new approach to helping people visualize systems.

- Preliminary literature reviews at several points found huge amounts of relevant sources related to specific facets of work (such as making decisions and communicating) but almost nothing specifically about the idea of facets of work.

- The idea of facets of work was developed as an extension of WST but can be used effectively independent of WST. That left a quandary about how to explain the idea without lengthy detours devoted to explaining WST and false starts and changes in direction that are best understood in relation to WST.

Despite those issues, the idea of facet of work is potentially valuable in many ways that will be discussed. For example, aside from potential use in helping people visualize systems in organizations, it can be used to visualize important aspects of the increasingly visible topic of division of labor between people and automated entities that might be viewed as algorithms, software agents, or even robots.

This paper proceeds as follows:

Section 2 defines facet of work and identifies underlying assumptions and criteria for identifying a type of activity as a facet of work. It summarizes how 18 facets of work were identified through an iterative process. Other researchers trying to identify facets of work likely would have identified some of those facets but might have been satisfied with 3 facets or 15 or 23 . Thus, improving on the 18 facets is a possible topic for future research.

Section 3 amplifies the abstract presentation of facets of work in Section 2 by presenting three examples illustrating how all 18 facets could be applied to specific situations. The first two are hypothetical examples designed to illustrate how facets of work might be useful for describing and analyzing the division of labor between people and automated entities. The third is a published real-world example that illustrates the broad relevance of the 18 facets.

Section 4 discusses consolidating basic knowledge about facets of work and organizing that knowledge to make it more accessible.

Section 5 identifies possible applications of facets of work in tools and lightweight SA\&D methods and in future research.

The Appendix is divided into two parts. Appendix 1 explains how the idea of facets of work is an extension of work system theory (WST) that was developed through a set of disconnected efforts that occurred years apart. It also mentions other uses of the term facet that appear in research in other fields. Presenting that background information after the main body of the paper reflects concerns that the paper's main purpose might be diffused by a discussion of the disjointed steps that developed the idea of facets of work.

Appendix 2 presents six lengthy tables that each cover one aspect or another of the 18 facets. These tables are relegated to the Appendix because including tables in the main body would make the narrative choppy and difficult to follow. These tables have practical importance, however, because they form the basis of the tools, methods, and future research mentioned in Section 5.

\section{The Idea of Facet of Work}

The term facet is often defined as one side of something that is many-sided. By analogy, a facet of work is one of many sides of work activities. A facet of work is a generic aspect of work that applies in many, but not necessarily all work systems in organizational settings. In that context, work consists of activities performed to produce product/services for internal and/or external customers by using human, informational, physical, and other resources. 
The idea of facets of work is almost totally absent from the literature even though the individual facets such as making decisions, communicating and coordinating are mentioned frequently. An Jan. 19, 2021 search on Google Scholar for "facets of work" returned only 3790 hits, almost all of which were about other topics such as facets of work value, facets of work-life balance, facets of work autonomy, facets of work support, and facets of work method ambiguity.

Table 1 identifies 18 common facets of work that can be used for discussing and exploring activities, processes, operational systems, and business ecosystems at various levels of depth. Each facet brings related concepts and other knowledge even though some facets overlap to some extent. Basic understandings of how the facets apply to specific situations does not rely on rigorous diagramming tools that belong in subsequent analysis, design, and problem solving. The 18 facets of work in Table 1 are discussed throughout this paper, with much more detail in tables in the Appendix.

Table 1. 18 Facets of Work

\begin{tabular}{|l|l|l|l|l|l|}
\hline Making decisions & $\begin{array}{l}\text { Representing } \\
\text { reality }\end{array}$ & Learning & Coordinating & $\begin{array}{l}\text { Performing } \\
\text { physical work }\end{array}$ & $\begin{array}{l}\text { Providing } \\
\text { service }\end{array}$ \\
\hline Communicating & $\begin{array}{l}\text { Applying } \\
\text { knowledge }\end{array}$ & Planning & Improvising & $\begin{array}{l}\text { Performing } \\
\text { support work }\end{array}$ & Creating value \\
\hline $\begin{array}{l}\text { Providing } \\
\text { information }\end{array}$ & Thinking & $\begin{array}{l}\text { Controlling } \\
\text { execution }\end{array}$ & $\begin{array}{l}\text { Processing } \\
\text { information }\end{array}$ & $\begin{array}{l}\text { Interacting } \\
\text { socially }\end{array}$ & $\begin{array}{l}\text { Maintaining } \\
\text { security }\end{array}$ \\
\hline
\end{tabular}

The following assumptions clarify the purpose and scope of the idea of facets of work:

- Focus on activity. Each facet of work is identified using a verb or verb phrase since work in business settings always involves activities that are expressed using verbs.

- Broad applicability. The various facets of work can be applied for thinking about specific realworld activities, capabilities, processes, operational systems, and business ecosystems. They can be used in survey research and for coding situations in case study research. They also can be applied to discussions of digital transformation, digitalization, and other phenomena that have little practical meaning unless work is performed.

- Multiplicity of facets. Work can be visualized as having many facets. For example, work related to hiring new employees in a specific situation includes activities that may involve many of the facets in Table 1. People initiating analysis of that situation can explore questions about facets of the relevant work without needing to document operational details, performance levels, or other information that deeper analysis would require.

- Generic concept. The concept of facet of work is generic. I.e., the same facets and related ideas can apply to many different situations. The 18 facets in Table 1 apply to work in many situations even though a given facet may not apply significantly to work in some specific situations.

- Inclusion criteria for facets. The 18 facets were chosen because they are easily understood, widely applicable, and associated with concepts and other knowledge related to business situations. Table A1 in Appendix 1 summarizes the frequent importance of each facet.

- Independence not required. There is no need for the facets to be totally independent. Facets of work may overlap, as when making decisions (one of the facets) in a situation involves processing information and communicating (two other facets). People describing, analyzing, or designing systems will not be sidetracked if some concepts related to decision making (e.g., speed, cost, and accuracy) are also relevant to other facets. The key issue is whether each facet brings important concepts and other knowledge that should be readily accessible for use.

- Applicability to sociotechnical and totally automated systems. Almost all facets apply equally to sociotechnical work performed by people and totally automated work performed by machines. (see Table A2 in Appendix 2). The main exception is the facet interacting socially, and even that one might be used in some way for modelling a totally automated work system or an ecosystem consisting of automated entities that interact in a quasi-social manner in the future. 
- Facet-related concepts and knowledge. Each facet is associated with concepts and other knowledge that is associated more directly with that facet than with other facets. (see Table A3)

- Evaluation criteria and design tradeoffs. Most facets bring or imply widely recognized evaluation criteria and design tradeoffs. (see Table A4)

- Sub-facets. Many facets have broadly applicable sub-facets. For example, sub-facets of information processing include capturing, transmitting, storing, deleting, retrieving, manipulating, and displaying information. (see Table A5).

- Open-ended questions. Most facets suggest questions that can be used in initial stages of describing or analyzing activities, capabilities, processes, operational systems, and ecosystems. (see Table A6).

\subsection{Selection of the $\mathbf{1 8}$ Facets}

The 18 facets were selected in a largely informal manner starting with some of the related ideas from earlier research described in Appendix 1. An initial small set of facets was expanded iteratively by considering whether personally familiar IS articles and real-world situations might suggest possible facets of work that were not yet included in the evolving list of facets. An aspect of activities in business organizations might be included tentatively in the evolving list of facets if it satisfied four criteria: 1) it is easily understood, 2) it is widely applicable, 3 ) it is identifiable using a verb phrase (since it is an aspect of an activity), and 4) it is associated with a set of concepts and other knowledge that is more related to that facet than to other facets. Some ideas initially on the list were replaced by synonyms or near-synonyms that met the four criteria more fully. The idea of facets was discussed at conferences and workshops in 2019 and 2020 and benefitted from comments by reviewers of conference submissions and by conference attendees. It was applied to varying degrees in five papers accepted for presentation at international conferences or workshops (Alter, 2019; 2020a; 2020b; 2020d; 2021).

An improved set of facets might be generated through additional exposure, discussion, and application of the current version or of an updated version of the facets. Deriving a formally justified set of facets in the future might be worthwhile if initial applications of the idea of facets of work proves useful in practice or in future research.

\section{Examples Illustrating the Relevance of Facets of Work}

This section provides three examples illustrating how all 18 facets could be applied to specific situations, thereby amplifying the initial understanding of facets of work from the previous Section.

- The first is a hypothetical example used in an ECIS 2020 paper (Alter, 2020b) to explain how the idea of facets of work might help in understanding the division of labor between people and robots in Industry 5.0. That use of the idea of facets of work sprang from curiosity about what the term Industry 5.0 might mean since it was part of the name of an ECIS mini-track but was not defined carefully. The hypothetical example presented here could be converted into facetbased descriptions of realistic examples related to situations that call for a combination of competence, collaboration, and improvisation, e.g., high level management processes, crisis response, operation of distributed teams, physical processes requiring coordinated effort of people and machines, and so on.

- The second example involves a hypothetical hiring system that uses several Al-based modules provided by a vendor (Alter, 2020d). That example was used in a paper that focused on seeing Al through the somewhat neutral metaphor of algorithm instead of hype- and fear-related metaphors and concerns ranging from smart machines and machine intelligence to ethical lapses and machine replacement vs. augmentation of people and machines.

- The third is a real-world example that illustrates the broad relevance of the 18 facets by showing that all of them were touched upon by direct quotations from a famous surgeon/author's case study called "The Update: Why Doctors Hate Computers" (Gawande, 2018). 


\subsection{Example: Tennis Lessons from an Imagined Robotic Tennis Instructor}

The artificial example of tennis lessons from an imagined robotic tennis instructor was developed for an ECIS 2020 mini-track concerning sociotechnical aspects of Industry 5.0. The content of Figure 1 was produced for a 12-minute remote presentation constrained by the very limited remote format of ECIS 2020. Explaining the paper and the facets of work in just 12 minutes required an example that would allow going through 18 facets very quickly. The 18 slides consolidated into Figure 1 look cartoonish but nonetheless provided a simple way to show that all 18 facets are potentially relevant to a situation involving collaboration between people and robots. The example illustrates why a deep look at sociotechnical aspects of almost any Industry 5.0 situation involving collaboration between people and robots would require consideration of many of those facets of work.

Notice that the 18 facets reveal many issues that would be ignored or downplayed if analysts relied heavily on typical SA\&D tools such as BPMN and entity-relationship diagrams to model the situation. Those tools are best suited to focus on mechanical process steps, such as creating an availability schedule, enrolling students, taking payment, scheduling lessons, recording student progress, and updating the robot's program. BPMN models of those steps would reveal little about important sociotechnical issues related to the person-robot collaboration required in the lessons themselves. 

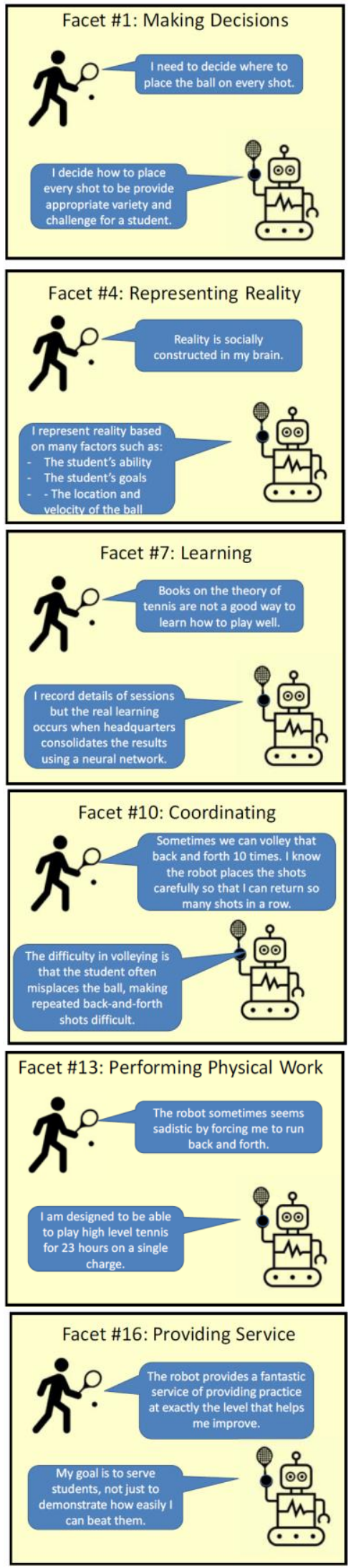
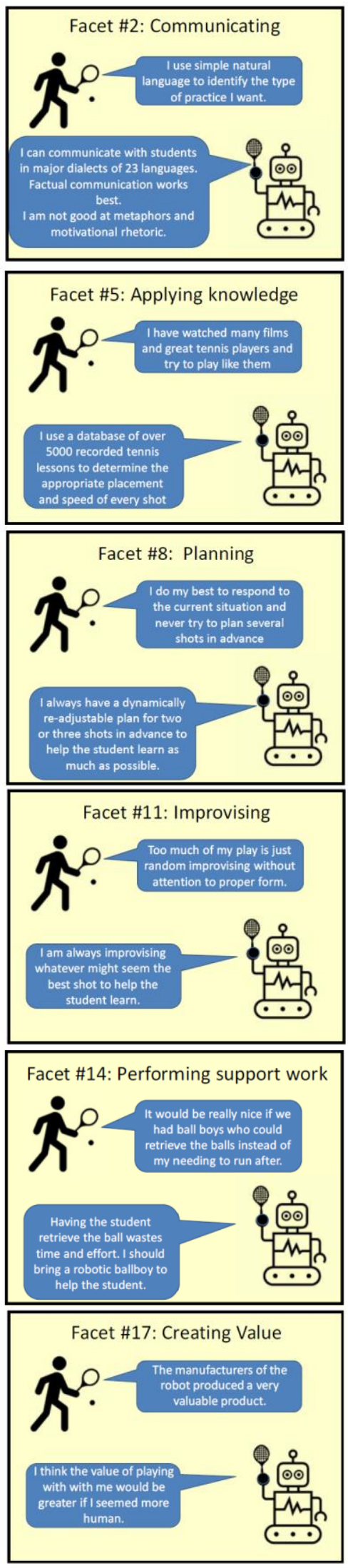
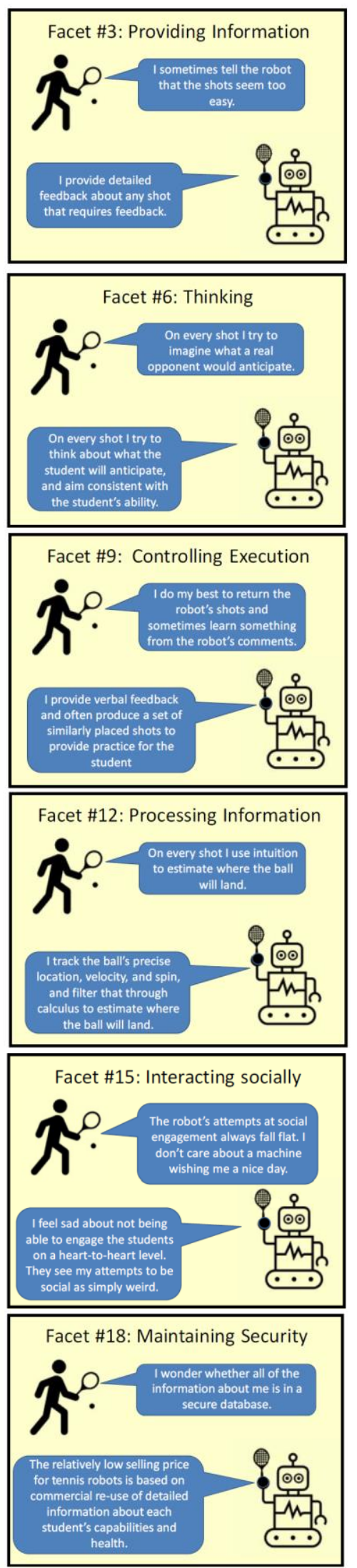

Figure 1. Hypothetical Robotic Tennis Lesson Illustrating 18 Facets of Work 


\subsection{A Hypothetical Hiring System that Uses AI}

Figure 2 is a formatted summary of a hypothetical hiring system that was used in Alter (2020d) as an introductory example for illustrating a way to think about the role of $\mathrm{Al}$ in an operational work system. That example and that paper's other introductory material provided background for comparing five real world examples presented at an $\mathrm{Al}$ conference. For current purposes, this example illustrates the potential use of facets of work for identifying important issues related to a work system that is to be improved.

In this example, PQR Corp implemented a new hiring work system two years ago to improve a previous hiring work system that absorbed too much effort inside PQR Corp and was so slow that good candidates sometimes went other companies before receiving offers. Also, it hired too many candidates who proved unsuitable and left before becoming productive. The new hiring work system used AlgoComm and AlgoRank from a suite of Al-based software tools provided by AlgoCorp. AlgoComm provided capabilities for posting job ads, receiving applications, setting up interview appointments, and performing other communication with candidates. AlgoRank ranked candidates based on job criteria and a neural network application driven by AlgoCorp's extensive database of job qualifications, salaries, and other information. Managers are analyzing the situation because some of the original issues persist and because new issues have arisen.

\begin{tabular}{|c|c|c|c|}
\hline \multicolumn{2}{|c|}{ Customers } & \multicolumn{2}{|c|}{ Product/services } \\
\hline \multicolumn{2}{|c|}{$\begin{array}{l}\text { - } \text { Applicants } \\
\text { - } \text { Hiring manager } \\
\text { - } \text { HR manager (who will use the applications to } \\
\text { analyze the nature of applicants) }\end{array}$} & \multicolumn{2}{|c|}{$\begin{array}{l}\text { - } \text { Applications (which may be used for } \\
\text { subsequent analysis) } \\
\text { - Job offers } \\
\text { - } \text { Rejection letters } \\
\text { - Hiring of the applicant }\end{array}$} \\
\hline \multicolumn{4}{|c|}{ Major activities and processes } \\
\hline \multicolumn{2}{|c|}{$\begin{array}{l}\text { - AlgoComm publicizes the position. } \\
\text { - Applicants submit resumes to AlgoComm. } \\
\text { - AlgoRank selects shortlisted applicants and } \\
\text { sends the list to the hiring manager. } \\
\text { - Hiring manager decides who to interview. } \\
\text { - AlgoComm sets up interviews. }\end{array}$} & \multicolumn{2}{|c|}{$\begin{array}{l}\text { - Interviewers perform interviews and provide } \\
\text { comments about applicants. } \\
\text { - AlgoRank evaluates candidates. } \\
\text { - Hiring manager makes hiring decision. } \\
\text { - AlgoComm notifies applicants. } \\
\text { - Applicant accepts or rejects job offer. }\end{array}$} \\
\hline Participants & \multicolumn{2}{|c|}{ Information } & Technologies \\
\hline $\begin{array}{l}\text { - Hiring manager } \\
\text { - Applicants } \\
\text { - Other employees } \\
\text { who perform } \\
\text { interviews }\end{array}$ & $\begin{array}{l}\text { - Job requisition } \\
\text { - Job description } \\
\text { - Advertisements } \\
\text { - Job applications } \\
\text { - Cover letters } \\
\text { - Applicant resumes }\end{array}$ & $\begin{array}{l}\text { - Applicant short list } \\
\text { - Information and } \\
\text { impressions from the } \\
\text { interviews } \\
\text { - Job offers } \\
\text { - Rejection letters }\end{array}$ & $\begin{array}{ll}\text { - } & \text { AlgoComm } \\
\text { - } & \text { AlgoRank } \\
\text { - Office software } \\
\text { - Internet }\end{array}$ \\
\hline
\end{tabular}

Figure 2. Formatted summary of a hypothetical hiring system that uses Al

Figure 2 summarizes the type of information that typically would be compiled and discussed to make sure stakeholders agreed about the nature and scope of the system and the issues that needed to be analyzed in more depth, e.g., concerns about different aspects of work system performance, structure, compliance and non-compliance, key incidents, perceptions of IS user satisfaction, and so on. Looking at the facets of work in this situation would help them understand the situation in more depth. Table 2 shows some of the questions that might have been studied. Notice that such questions might not have been pursued without attention to the facets of work. 
Table 2. Issues related to Al that might be pursued concerning the hiring system in Figure 2.

\begin{tabular}{|c|c|}
\hline Facet & $\begin{array}{l}\text { Issues related to potential use of Al in the hiring system } \\
\end{array}$ \\
\hline $\begin{array}{l}\text { Making } \\
\text { decisions }\end{array}$ & $\begin{array}{l}\text { How could Al support decisions more fully in this system? Should Al suggest } \\
\text { decisions or make decisions? }\end{array}$ \\
\hline Communicating & $\begin{array}{l}\text { How could Al explain how it makes or suggests decisions? How can Al help work } \\
\text { system participants communicate more effectively? }\end{array}$ \\
\hline $\begin{array}{l}\text { Providing } \\
\text { information }\end{array}$ & $\begin{array}{l}\text { Could Al provide more meaningful information to work system participants than } \\
\text { would otherwise be available? }\end{array}$ \\
\hline $\begin{array}{l}\text { Representing } \\
\text { reality }\end{array}$ & $\begin{array}{l}\text { Does Al represent reality in a biased way? For example, what about possible bias } \\
\text { or omissions in the dataset used to train a neural network? }\end{array}$ \\
\hline $\begin{array}{l}\text { Applying } \\
\text { knowledge }\end{array}$ & $\begin{array}{l}\text { Could Al identify and provide specific knowledge that would help in evaluating } \\
\text { applicants? }\end{array}$ \\
\hline Thinking & $\begin{array}{l}\text { Are there any areas in which it would be beneficial for Al to replace or augment } \\
\text { thinking done by work system participants? }\end{array}$ \\
\hline Learning & $\begin{array}{l}\text { Could Al learn from the success or problems with previous hires in order to support } \\
\text { better hiring decisions in the future? }\end{array}$ \\
\hline Planning & $\begin{array}{l}\text { Could Al help in planning hiring schedules and interview schedules in ways that } \\
\text { minimize interference with ongoing work by interviewers? }\end{array}$ \\
\hline $\begin{array}{l}\text { Controlling } \\
\text { execution }\end{array}$ & $\begin{array}{l}\text { Could Al help in controlling interview processes to assure that the strongest } \\
\text { candidates received priority in screening processes? }\end{array}$ \\
\hline Coordinating & $\begin{array}{l}\text { How could Al support better coordination between interviewers and between } \\
\text { applicants and interviewers in terms of convenience? }\end{array}$ \\
\hline Improvising & $\begin{array}{l}\text { How could Al support any necessary improvising, such as identifying appropriate } \\
\text { workarounds when standard processes prove cumbersome? }\end{array}$ \\
\hline $\begin{array}{l}\text { Processing } \\
\text { information }\end{array}$ & $\begin{array}{l}\text { Can Al play any special role in capturing, transmitting, storing, retrieving, deleting, } \\
\text { manipulating, or displaying information? }\end{array}$ \\
\hline $\begin{array}{l}\text { Performing } \\
\text { physical work }\end{array}$ & $\begin{array}{l}\text { Use of Al to assess physical work would be relevant mainly if job responsibilities } \\
\text { involved physical work that could be sampled and evaluated. }\end{array}$ \\
\hline $\begin{array}{l}\text { Performing } \\
\text { support work }\end{array}$ & $\begin{array}{l}\text { How could Al perform support work that might help interviews proceed more } \\
\text { efficiently and with fewer interruptions? }\end{array}$ \\
\hline $\begin{array}{l}\text { Interacting } \\
\text { socially }\end{array}$ & $\begin{array}{l}\text { Could Al do more to support social interactions during interviews and evaluation } \\
\text { processes? }\end{array}$ \\
\hline $\begin{array}{l}\text { Providing } \\
\text { service }\end{array}$ & $\begin{array}{l}\text { How could Al make the entire hiring experience seem like more of a service to } \\
\text { applicants (thereby swaying them in the firm's favor)? }\end{array}$ \\
\hline Creating value & $\begin{array}{l}\text { How could Al help both applicants and interviewers feel that they receive more } \\
\text { value for their efforts across the hiring process? }\end{array}$ \\
\hline $\begin{array}{l}\text { Maintaining } \\
\text { security }\end{array}$ & $\begin{array}{l}\text { How could Al help in maintaining information security for applicants, interviewers, } \\
\text { and the firm as a whole? }\end{array}$ \\
\hline
\end{tabular}

\subsection{Using Facets of Work to Illuminate Important Aspects of a Case Study}

A test of the practical value of facets of work is whether the 18 facets of work appear in non-trivial ways in real world situations. This section uses a case study called "The Update: Why Doctors Hate Their Computers" (Gawande, 2018) to demonstrate the practical relevance of the 18 facets. In the case study, a surgeon describes experience related to the $\$ 1.6$ billion implementation of the EPIC electronic medical records (EMR) system in Partners HealthCare, which has 70,000 employees, 12 hospitals, and hundreds of clinics in New England, USA. Under $\$ 100$ million was for software. Most of the rest was for "lost patient revenues and all the tech-support personnel and other people needed during the implementation phase." Gawande's account recognizes the value of the EMR system but as implied by its title does not support aspirational views of EMR as providing complete and accurate patient information, eliminating vulnerabilities of paper, facilitating communication, assuring consistency, and improving evaluation of medical treatments. Instead, he says, "Doctors are among the most technology avid people in society; computerization has simplified tasks in many industries. Yet somehow we've reached a point where people in the medical profession actively, viscerally, volubly hate their computers." (p. 62)

Table 3 uses quotations from the case to illustrate that all 18 facets were mentioned, either directly or indirectly, by a surgeon who wrote the case study for a non-specialist audience. The apparent goal was to describe what he saw as the essence of an important real-world situation that mattered greatly to him and 
his colleagues, and that well-informed citizens should know about. He had no prior knowledge of the idea of facets of work, which had not been proposed at the time the case study was written.

The use of the 18 facets to organize quotations in Table 3 supports the belief that the facets of work are topics that matter in practice. Some quotations could be moved to other categories, but it is noteworthy that every facet was present at least to some degree. The facets with the least direct quotations in Table 3 are planning (represented by mentioning a treatment plan) and performing physical work (implicit in the fact that the author talks about being a surgeon and therefore spending little time entering data into the EMR system). The significance of finding quotations related to all 18 facets should not be exaggerated but notice how typical SA\&D approaches easily could have missed many issues that a tech-savvy surgeon viewed as important for understanding realities resulting from implementing an EMR system in his organization. Discussion of the various facets of work might have helped in anticipating and addressing some of the problems that led the surgeon-author to write an article with the subtitle "why doctors hate their computers."

Table 3. Quotations related to facets of work, from an EMR case study (Gawande, 2018)

\begin{tabular}{|c|c|}
\hline Facet & Quotation from the case study \\
\hline $\begin{array}{l}\text { Making } \\
\text { decisions }\end{array}$ & $\begin{array}{l}\text { "Perhaps a computer could have alerted me to the possibility of a genetic disorder in [a } \\
\text { patient], based on his history of skin lesions and the finding of high calcium. (p. 73) }\end{array}$ \\
\hline Communicating & $\begin{array}{l}\text { [Her] "in Basket" ... had become ... "clogged to the point of dysfunction. There are messages } \\
\text { from patients, messages containing lab and radiology results, messages from colleagues, } \\
\text { messages from administrators, automated messages about not responding to previous } \\
\text { messages. "All the letters that come from the subspecialists, I can't read ninety per cent of } \\
\text { them. So I glance at the patient's name, and, if it's someone that I was worried about, I'll read } \\
\text { that," she said. The rest she deletes, unread." (p. 66) }\end{array}$ \\
\hline $\begin{array}{l}\text { Providing } \\
\text { information }\end{array}$ & $\begin{array}{l}\text { "From my computer, I could now remotely check the vital signs of my patients recovering from } \\
\text { surgery in the hospital. With two clicks, I could look up patient results from outside institutions } \\
\text { that use Epic, as many now do." (p. 64) }\end{array}$ \\
\hline $\begin{array}{l}\text { Representing } \\
\text { reality }\end{array}$ & $\begin{array}{l}\text { A doctor "manages a large number of addiction patients, and has learned how to use a list to } \\
\text { track how they are doing as a group, something she could never have done on her own." The } \\
\text { EMR supports new ways to "identify patients who have been on opioids for more than three } \\
\text { months in order to provide outreach and reduce the risk of overdose." (p. 66) }\end{array}$ \\
\hline $\begin{array}{l}\text { Applying } \\
\text { knowledge }\end{array}$ & $\begin{array}{l}\text { "Doctors' handwritten notes were brief and to the point. With computers, however, the shortcut } \\
\text { is to paste in whole blocks of information-an entire two-page imaging report, say-rather } \\
\text { than selecting the relevant details. The next doctor must hunt through several pages to find } \\
\text { what really matters. Multiply that by twenty-some patients a day, and you can see [her] } \\
\text { problem." (p. 65) }\end{array}$ \\
\hline Thinking & $\begin{array}{l}\text { "Our systems are forever generating alerts about possible connections-to the point of signal } \\
\text { fatigue. Just ordering medications and lab tests triggers dozens of alerts each day, most of } \\
\text { them irrelevant, and all in need of human reviewing and sorting. There are more surprises, not } \\
\text { fewer. The volume of knowledge and capability increases faster than any individual can } \\
\text { manage-and faster than our technologies can make manageable for us. We ultimately need } \\
\text { systems that make the right care simpler for both patients and professionals, not more } \\
\text { complicated." (p. 73) }\end{array}$ \\
\hline Learning & $\begin{array}{l}\text { "There was a column of thirteen tabs on the left side of my screen, crowded with nearly } \\
\text { identical terms: "chart review," "results review," "review flowsheet." We hadn't even started } \\
\text { learning how to enter information, and the fields revealed by each tab came with their own } \\
\text { tools and nuances. (p. 62) }\end{array}$ \\
\hline Planning & $\begin{array}{l}\text { "Cameron's situation was too complicated for a thirty-minute slot. We'd gone way over time. } \\
\text { Other patients were waiting. Plus, I still had to type up all my findings, along with our } \\
\text { treatment plan." }\end{array}$ \\
\hline $\begin{array}{l}\text { Controlling } \\
\text { execution }\end{array}$ & $\begin{array}{l}\text { The chief clinical officer supervised the software upgrade and remained focused on long-term } \\
\text { concerns such as maintaining control and quality. He was happy to have change control } \\
\text { processes and execution controls that would help the hospitals avoid unsafe medical practices } \\
\text { that could not be found in the paper-based world, such as nonstandard treatments of congestive } \\
\text { heart failure. (p.68) }\end{array}$ \\
\hline Coordinating & $\begin{array}{l}\text { "Each patient has a "problem list" with his or her active medical issues, such as difficult-to- } \\
\text { control diabetes, early signs of dementia, a chronic heart-valve problem. The list is intended to } \\
\text { tell clinicians at a glance what they have to consider when seeing a patient. [A physician] used } \\
\text { to keep the list carefully updated-deleting problems that were no longer relevant, adding }\end{array}$ \\
\hline
\end{tabular}




\begin{tabular}{|c|c|}
\hline & $\begin{array}{l}\text { details about ones that were. But now everyone across the organization can modify the list, } \\
\text { and, she said, "it has become utterly useless." Three people will list the same diagnosis three } \\
\text { different ways. Or an orthopedist will list the same generic symptom for every patient ("pain in } \\
\text { leg"), which is sufficient for billing purposes but not useful to colleagues who need to know the } \\
\text { specific diagnosis." (p. 64) }\end{array}$ \\
\hline Improvising & $\begin{array}{l}\text { [as a result of change controls] "Artisanship has been throttled, and so has our professional } \\
\text { capacity to identify and solve problems through ground-level experimentation." (p.68) }\end{array}$ \\
\hline $\begin{array}{l}\text { Processing } \\
\text { information }\end{array}$ & $\begin{array}{l}\text { "Ordering a mammogram used to be one click," she said. "Now I spend three extra clicks to } \\
\text { put in a diagnosis. When I do a Pap smear, I have eleven clicks. It's 'Oh, who did it?' Why not, } \\
\text { by default, think that I did it?" She was almost shouting now. "I'm the one putting the order in. } \\
\text { Why is it asking me what date, if the patient is in the office today? When do you think this } \\
\text { actually happened? It is incredible!" (p.65) }\end{array}$ \\
\hline $\begin{array}{l}\text { Performing } \\
\text { physical work }\end{array}$ & $\begin{array}{l}\text { "As a surgeon, though, I spend most of my clinical time in the operating room. I wondered how } \\
\text { my more officebound colleagues were faring." (p. 64) [Thus, the author performs the physical } \\
\text { work of surgery, but issues related to that physical work are not discussed in the case.] }\end{array}$ \\
\hline $\begin{array}{l}\text { Performing } \\
\text { support work }\end{array}$ & $\begin{array}{l}\text { "A longtime office assistant ... said that each new software system reduced her role and } \\
\text { shifted more of her responsibilities onto the doctors. Previously, she sorted the patient records } \\
\text { before clinic, drafted letters to patients, prepped routine prescriptions - all tasks that lightened } \\
\text { the doctors' load. None of this was possible anymore. The doctors had to do it all themselves. } \\
\ldots \text {.. She couldn't even help the doctors navigate and streamline their computer systems: office } \\
\text { assistants have different screens and are not trained or authorized to use the ones doctors } \\
\text { have." ... [she] felt sad and sometimes bitter about this pattern of change: "It's } \\
\text { disempowering. It's sort of like they want any cookie-cutter person to be able to walk in the } \\
\text { door, plop down in a seat, and just do the job exactly as it is laid out." (p. 66) }\end{array}$ \\
\hline $\begin{array}{l}\text { Interacting } \\
\text { socially }\end{array}$ & $\begin{array}{l}\text { "I began to see the insidious ways that the software changed how people work together. } \\
\text { They'd become more disconnected; less likely to see and help one another, and often less } \\
\text { able to." (p. 66) }\end{array}$ \\
\hline $\begin{array}{l}\text { Providing } \\
\text { service }\end{array}$ & $\begin{array}{l}\text { "A } 2016 \text { study found that physicians spent about two hours doing computer work for every } \\
\text { hour spent face to face with a patient-whatever the brand of medical software. In the } \\
\text { examination room, physicians devoted half of their patient time facing the screen to do } \\
\text { electronic tasks." (p. 62) }\end{array}$ \\
\hline Creating value & $\begin{array}{l}\text { [according to the chief clinical officer] "We think of this as a system for us and it's not," he } \\
\text { said. "It is for the patients." While some sixty thousand staff members use the system, almost } \\
\text { ten times as many patients log into it to look up their lab results, remind themselves of the } \\
\text { medications they are supposed to take, read the office notes that their doctor wrote in order to } \\
\text { better understand what they've been told." (p. 66) }\end{array}$ \\
\hline $\begin{array}{l}\text { Maintaining } \\
\text { security }\end{array}$ & $\begin{array}{l}\text { (See the quotation on performing support work. The restrictions on accessing information are } \\
\text { partly about maintaining security.) }\end{array}$ \\
\hline
\end{tabular}

\section{Consolidating Basic Knowledge about Facets of Work}

The three examples in the previous section illustrate different aspects of the potential usefulness of facets of work. The relatively familiar and easily understood nature of the direct quotations in the EMR case study (Table 3) makes it seem likely that many of the facets will be relevant in discussions or descriptions of many systems in business and organizational settings. The nature of the list of issues (Table 2) related to facets of work in the hypothetical hiring system makes it seem plausible that similar issues related to facets of work might apply to many Al applications and to many other ICT applications as well. The application of the facets of work to the hypothetical example of robotic tennis lessons shows that attention to facets of work might be useful in looking at collaboration between people and automated entities, an increasingly important topic as important responsibilities are increasingly assigned to automated entities More broadly, the example shows how the facets of work can be used for visualizing aspects of many situations that call for some form of organized analysis even though they do not contain highly structured processes.

Consolidating basic knowledge about facets of work is a step toward developing new tools and methods for describing and analyzing systems in business and organizational settings. To demonstrate that idea, entries in Table 4 illustrates some of the basic knowledge about a single facet, making decisions.

The entries in Table 4 are meant to be illustrative and could be improved and expanded in many ways. The first entry summarizes why the facet making decisions is of broad significance. The second entry shows that 
the facet making decisions applies to both sociotechnical systems some of whose human participants use technologies and totally automated systems that operate autonomously after being triggered by people, by automated entities, by conditions, or by other factors. The third entry identifies a selection of concepts that are associated with making decisions. Many other concepts could have been included. The next two entries identify common evaluation criteria and tradeoffs associated with making decisions. The sixth entry identifies sub-facets of making decisions, i.e., typical generic steps in decision processes. The seventh entry identifies typical open-ended questions that might be useful in starting a discussion about how and how well decisions are made in a particular situation.

Table 4: Issues and ideas associated with making decisions, one of 18 facets of processes and activities

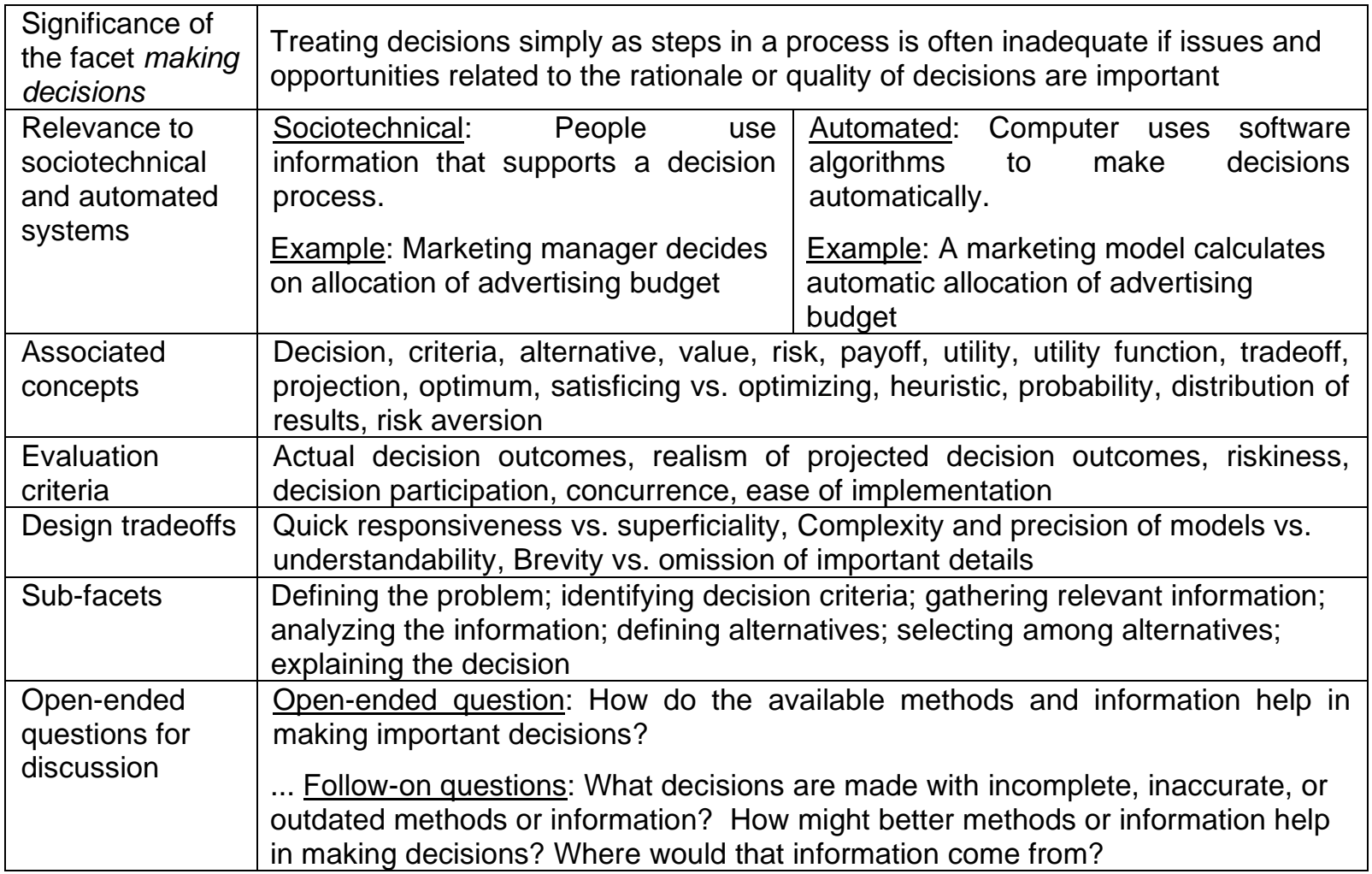

The six tables in Appendix 2 demonstrate consolidation of knowledge related to facets of work by showing the types of information for all 18 facets discussed here. The Introduction noted that those lengthy tables are deferred to Appendix 2 because including them in the body of the paper would make the narrative choppy and difficult to follow. As with Table 4, the tables in Appendix 2 are meant as illustrative examples of knowledge associated with each of the 18 facets. Readers who look at those tables will recognize many common concepts, evaluation criteria, and tradeoffs. They probably will be able to suggest additional ideas that were not included. Thus, the content of those tables is not meant to be definitive or exhaustive. Rather, the examples in the tables are meant to demonstrate the possibility of compiling valuable knowledge that could be used when people try to analyze systems, just as compilations of medical knowledge and legal knowledge sometimes are useful to physicians and lawyers and just as checklists are useful in many situations involving established procedures or knowledge (e.g., Gawande, 2010).

\section{Potential Applications of Facets of Work}

The facets of work bring concepts and other types of knowledge that typically are viewed as peripheral to SA\&D, to systems in general, and to speculative discussions of digital transformation, digital innovation, and digitalization. This section identifies some of the many areas in which the facets of work might prove helpful. 


\subsection{Supporting analysis and design of activities, processes, operational systems, and business ecosystems}

SA\&D starts with requirements determination but often is associated with a process of creating rigorously documented specifications of software/hardware used by people or embedded within objects. Emphasis on rigorous documentation increases the likelihood of creating high quality software, but may lead to ignoring business, social, and conceptual issues that are relevant to analyzing and designing systems for efficiency and effectiveness.

The facets of work provide an organized and straightforward way to identify issues that might otherwise be missed when focusing mostly on process specifications and technical requirements. The facet-related concepts, evaluation criteria, design tradeoffs, and sub-facets (see Table 4 and tables in Appendix 2) all provide ways to guide discussions without requiring deep theoretical knowledge related to each facet. Facetspecific questions (again see Table 4 and Appendix 2) provide a path for going deeper.

Aspects of those topics surely are discussed in many SA\&D efforts even if they are not traversed in a systematic manner in most SA\&D approaches that are discussed widely. Pre-specified templates or interactive tools related to theoretical concepts, generalizations, and other knowledge for each topic might go much further.

The tables presented in Appendix 2 illustrate only a subset of the content that could go into online tools or other approaches for providing stakeholders with flexible access to useful knowledge that might support their deliberations. Thus, while parts of the tables might be used directly, the facets of work could be a basis for organizing and providing both non-abstract knowledge such as examples, stories, and statistical data and abstract knowledge such as design principles, frameworks, models, and theories related to specific facets (Alter, 2021).

Regardless of whether that type of ambition is ever realized, here is a simple, lightweight approach that allows an individual or group to use these ideas with the help of a web-based tool, a PowerPoint presentation, or simple checklists in the general spirit of those used in medical exams or in other procedures where it is important not to overlook important topics. This approach could be expanded to include knowledge of other types such as rules of thumb.

- Select one or several facets that seem relevant to the situation.

- For each of those facets:

- Briefly consider open-ended questions such as those in Table A6.

- If desired, support the deliberations by finding ideas about that facet in checklists, online tools or other representation of the content of Tables A3 (associated concepts), A4 (evaluation criteria and tradeoffs), and/or A5 (sub-facets)

- Discuss, take notes, or obtain relevant information.

- Repeat for other facets that might seem important in the situation at hand.

A practical feature of this approach is that it can be used independent of formal systems analysis or can be used in conjunction with existing SA\&D methods by simply adding new questions about facets of work at whatever level would likely generate insights quickly. Non-experts in any given facet would apply the relevant knowledge less precisely and less deeply than experts, but making those topics visible would be better than ignoring them.

\subsection{Supporting or extending various approaches and methods related to processes, systems and ecosystems}

Supporting agile development. Agile development is discussed a great deal without much agreement about exactly what it means beyond bearing some relation to parts of the Agile Manifesto (Beck et al., 2001). Even though agile development typically does not start with detailed plans and documentation, ideas related to facets of work could contribute in several ways. Identifying and discussing relevant facets of work at the beginning of an agile project would help in maintaining coherence by keeping key issues visible during the project. Looking at facets of work could lead to identifying issues that might be overlooked by focusing too much on software backlogs and the progress of sprints within agile development. 
Extending BPM - business process management. As with agile development, different scholars have different ideas of what BPM means. Some scholars see it as a combination of six core elements, strategic alignment, governance, methods, information technology, people, and culture (Rosemann and vom Brocke, 2015) and tend to focus on process-improvement methods (Bolsinger et al. 2015), BPM culture (vom Brocke and Sinnl, 2011), and related topics. Others focus more on extensions of workflow software, process models, and process automation, with emphasis on abstractions, BPM languages, and computerized methods.

Facets of work could extend ideas in Alter and Recker (2017), which suggests expanding the scope of BPM by superimposing ideas from WST and its extensions on top of 20 BPM research use cases described by van der Aalst (2013). BPM stakeholders who want to manage business processes should be interested in important issues related to facets of work rather than just details of process models and should find the facets of work potentially useful for visualizing issues related to existing or proposed processes. Scholars interested in extending the formal aspects of BPM might be interested in seeing whether and how the facets of work could extend some of the existing techniques and notations.

Extending EM - enterprise modelling. Focusing on facets of work might help in achieving some of the EM aspirations described in Sandkuhl et al. (2018), which proposes making EM less reliant on modelling experts. Business stakeholders who engage in EM discussions probably could contribute to discussions of facets of work without great difficulty. As with BPM, it seems possible that relatively high-level discussion of facets of work would fit with existing EM practices. Notice how this approach is quite different from streams of EM research that produce EM languages and rigorous modelling environments such as the MultiPerspective Enterprise Modeling capability called MEMO (Frank, 2014).

Analyzing business ecosystems. When considering business ecosystems from an enterprise viewpoint, key questions include what the enterprise contributes to an ecosystem and how that contribution might be improved or extended. Facets and sub-facets of work provide a starting point for thinking about many issues without becoming overwhelmed with contributions and interests of multiple participants that play different ecosystem roles. Most of the facets of work apply directly: How will this enterprise participate in important decisions in the ecosystem? How will it communicate with ecosystem partners -- mostly through messages in computerized transactions or through relationships and negotiation? Questions such as those lead directly to issues about which capabilities, processes, or systems are required and how the various facets of work will be handled.

\subsection{Supporting Empirical Research}

The idea of facets of work might be incorporated into empirical research about how requirements determination and SA\&D are performed in practice. The facets provide the basis of simple checklists that could be used to analyze meeting notes, formal documentation, recordings of interviews, and other indications of what was or was not considered during the project. Analysis of that type of information would provide empirical evidence about whether systematic consideration of facets of work in IS development projects is likely to lead to better business outcomes.

More broadly, the idea of facets of work could be used in case study research to identify topics that are or are not addressed by any formalized account of the situation. For example, facets of work could be used to code statements or concerns of people interviewed. They also could be used as prompts through open ended questions such as those in Table A6.

\subsection{Understanding digital transformations, digital innovations, and digitalization.}

The increasing frequency of commentaries about those terms has done little to attain agreement about exactly what they mean in practice (e.g., Demlehner \& Laumer, 2019; Vial, 2019). Looking at those ideas through the lens of facets and sub-facets of work could lead to new ways to understand what those terms mean in specific situations beyond just slogans for whatever currently seems new and exciting in the intersection between business and technology. Thinking in terms of facets of work could help in strategizing about digital transformations and digitalization because it could engage the imagination of business stakeholders around important aspects of business operations instead of focusing on vague aspirations or emerging technologies that they may not understand or appreciate fully. Even if inspired by abstractions or cherry-picked examples about potential of Al, big data, Internet of things, mobility, cloud computing, and/or social media, the discussion would try to identify and consider key issues related to specific facets of work in the current situation that might be addressed through an IT-based intervention. Delving into facets and 
possibly sub-facets of work in the situation could help many stakeholders appreciate how emerging technologies might bolster their internal and external capabilities or might present difficult threats and competitive challenges.

\subsection{Developing a better set of facets}

The figures and tables presented here might be viewed as a starting point for a bootstrap process of developing a better set of facets. That process could proceed in several ways. One approach is to accept the general characterization of the facets of work in Section 2 and to try to more powerful methods to develop a better list. Other individuals or teams trying to identify facets of work based on the same criteria likely would have identified making decisions, communicating, and processing information, but might have ignored some of the 18 facets and might have identified other plausible facets of work that are not included here. An attempt to develop a better list of facets would start by reviewing and possibly sharpening the criteria and then might proceed toward a better list by using various combinations or search methods, experience, and voting.

A fundamentally different approach is to extend the idea of facets of work beyond activities or groups of activities. For example, elements of various recognized frameworks might have been used for a broader view of facets of work that includes facets of the entities that perform the work, are affected by the work, or that affect the work in some way. Thus, the work system framework (Alter, 2013b) might have provided facets called customer, product/service, processes and activities, and so on. The Leavitt diamond model (Leavitt, 1964) might have provided four facets: people, task, structure technology. CATWOE from soft system methodology (Checkland, 2000) might have provided six facets: customers, actors, transformation process, worldview, owners, and environmental constraints. The main elements in diagrams summarizing activity theory (e.g. Engeström, 1990) might have provided mediating artifacts, subject, object, rules, community, division of labor, and outcome. Sub-models in the 4EM language for enterprise modelling might have brought goals, business rules, concepts, business processes, actors, and resources. (Stirna and Persson, 2018). At least one of the elements of each of those approaches refers specifically to activities or groups of activities. Expanding the idea of facets of work to include additional elements of any of those approaches would have resulted in a more complicated scheme that might be pursued in future research.

To illustrate this expanded approach, Figure 3 shows how the idea of facets of work might be expanded into a broader idea called facets of work systems. Figure 3 associates the facets of the work with the work system element processes and activities but also attaches other facets to the other eight elements of the work system framework and to work systems as a whole. For example, facets of the WS element participant include agent, technology user, and collaborator. Much knowledge related to participants is more closely linked to those facets rather than to participant in general, e.g., computer self-efficacy is more related to technology user than to agent or collaborator because many agents and collaborators do not use computers.

Expanding the idea of facets of work to facets of work systems might be useful in various ways even though some of the facets of work systems would not satisfy all of assumptions about facets of work that were mentioned in Section 2. For example, some of the facets of work systems overlap more than the facets of work as demonstrated by greater overlap involving associated concepts, evaluation criteria, and tradeoffs. Also, many of new facets in Figure 3 are not activities and therefore do not have the same type of subfacets even though they may have components or special cases. 


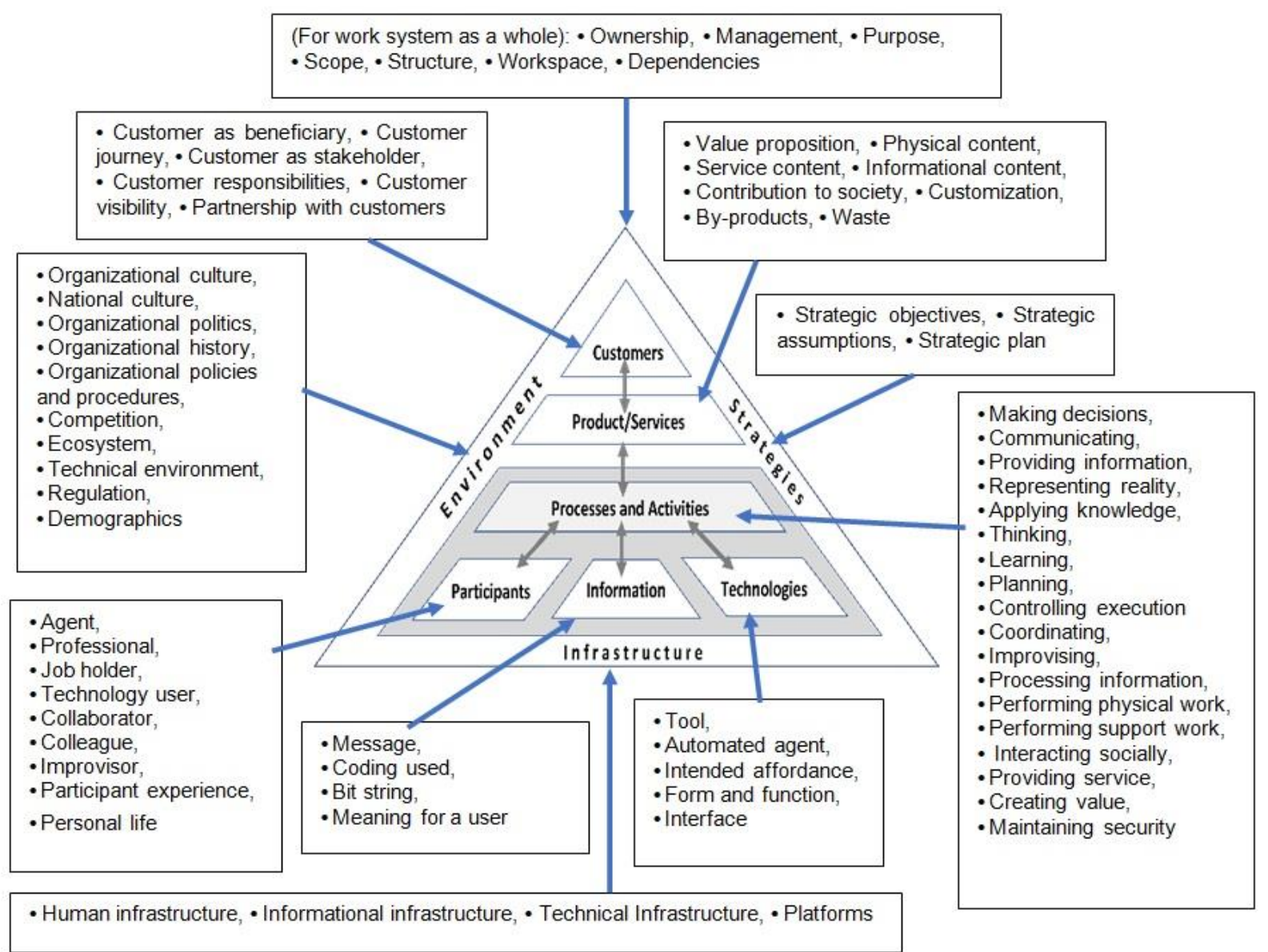

Figure 3. Expanding facets of work to facets of work systems

\subsection{Developing a Body of Knowledge for IS}

The need for an IS body of Knowledge, an ISBOK, or at least a shared language about IS has been discussed for at least several decades (e.g., Hirschheim and Klein, 2003). An ISBOK would be an organized set of ideas that are useful for understanding, analyzing, evaluating, and communicating about ISs that may be sociotechnical or totally automated. A variety of initiatives have addressed aspects of an ISBOK. Four examples that help in visualizing possible paths include 1) representation theory, 2) the AIS "Theories Used in IS Research Wiki," 3) compilation and organization of important articles, and 4) of constructs for IS research.

1) Ideas proposed by Wand \& Weber (1990), later called representation theory (Burton-Jones et al., 2017), says that an IS is a representation of a real-world system and ISs "are primarily intended to model the states and behavior of some existing or conceived real world system." Representation theory applies the BungeWeber-Wand (BWW) ontology and energized important research but omits many important IS topics such as how an IS is implemented, used, or managed, as noted in Wand \& Weber (1990, p. 62).

2) The "Theories Used in IS Research Wiki" (Larsen \& Eargle, 2018) summarizes many such theories, often without clarifying their domains, possibly because many such as the theory of planned behavior are not fundamentally about IS (which is also true of the facets of work).

3) A quite different approach tries to compile knowledge in the form of published articles. Hassan \& Mathiassen, 2018) relies on classification in proposing an IS Development BOK (ISDBOK) based on textual analysis covering 6643 Senior Scholars' Basket of Eight articles between 1978 and 2012. The result is "466 ISD articles that offer canonical ISD knowledge distinctive to IS and complementary to other disciplines." Using mechanical means to extract knowledge about specific facets of work from those articles probably would be quite difficult. 
4) Larsen \& Bong (2016) applied natural language processing algorithms for detecting whether two behavioral constructs refer to the same real-world phenomenon. Application to 193 articles in two Basket of Eight journals between 1983 and 2009 led to a construct taxonomy including 1004 constructs in 19 hierarchies, a result that is much more extensive than the content of the six tables in Appendix 2. Perhaps the six tables should not seem as lengthy as they might seem at first blush.

A possible step toward treating facets of work as part of an ISBOK is presented in a paper about an "openended knowledge model for visualizing, organizing, and accessing knowledge about information systems in organizational settings" (Alter, 2021). That paper proposes the rationale and structure of a work system knowledge model (WSKM) that constitutes a plausible approach for making progress toward an ISBOK. The WSKM assumes that knowledge objects include non-abstract knowledge such as data, examples, and stories and abstract knowledge such as concepts, generalizations, and methods. The proposed WSKM focuses on an essential part of the IS field, i.e., the creation, operation, and evolution of ISs in organizations. Facets of work are an integral part of that proposed WSKM because knowledge about facets of work constitute a significant part of the knowledge about information systems and other systems in organizations. Table 5 illustrates how the knowledge objects in the ISBOK might be recorded in a spreadsheet. Entries in the first column are knowledge objects. The second column, type of knowledge object is based on classifications from a taxonomy of knowledge objects in Alter (2020c). The third column, "most general type of work system" refers to special cases of work system such as totally automated information system, project, and open source software project. "Applies to" refers to whether the knowledge object refers to a work system as a whole (which may be a special case such as project), a specific element of the work system framework, or a facet of one of the work system elements.

Table 5: Illustration of a spreadsheet format for compiling knowledge objects for an ISBOK

\begin{tabular}{|l|l|l|l|}
\hline Knowledge Object & $\begin{array}{l}\text { Type of knowledge } \\
\text { object }\end{array}$ & Applies to & $\begin{array}{l}\text { Most general type } \\
\text { of work system }\end{array}$ \\
\hline Scalability & Characteristic & WS as a whole & WS in general \\
\hline Precision & Characteristic & Information & WS in general \\
\hline Accuracy & Area of performance & Information & WS in general \\
\hline Error rate & Area of performance & Processes and activities & WS in general \\
\hline Techno-stress & Phenomenon & Participants & Sociotechnical WS \\
\hline Start date & Characteristic & Processes and activities & Project \\
\hline Escalation of commitment & Phenomenon & Project as a whole & Project \\
\hline "Do the work efficiently" & Design principle & Processes and activities & WS in general \\
\hline TAM & Theory & Technology & WS in general \\
\hline Cognitive load theory & Theory & Participants & Sociotechnical WS \\
\hline Absorptive capacity & Phenomenon & WS as a whole & WS in general \\
\hline Agile manifesto & Design principle(s) & Software project & Software project \\
\hline Understandability & Area of performance & Communicating (a facet) & WS in general \\
\hline Coordination theory & Theory & Coordinating (a facet) & WS in general \\
\hline Responsiveness & Area of performance & $\begin{array}{l}\text { Providing service (a } \\
\text { facet) }\end{array}$ & WS in general \\
\hline Capturing information & Action & $\begin{array}{l}\text { Processing information } \\
\text { (a facet) }\end{array}$ & WS in general \\
\hline
\end{tabular}

Regardless of limitations in that approach to an ISBOK, the inclusion of facets of work in the WSKM raises the question of whether a valid ISBOK could simply ignore many or all of the18 facets, especially when a 
great deal of IS-related research is specifically about most of those facets. The need to include facets such as making decisions and communicating that appear near the beginning of the current list is most obvious, but many of the other facets are also important and are current focal points of research, e.g., interacting socially via ICT, performing physical work involving robots, providing service, and maintaining security.

\section{Conclusion}

The IS discipline and related disciplines have generated a substantial body of research results related to important topics that are barely mentioned in typical SA\&D methods, in everyday IS practice, or in the speculation and hype associated with digital transformation, digitalization, and artificial intelligence. Straightforward application of ideas related to facets of work could make more of that knowledge available for practitioners and managers without disrupting the benefits of existing methods. Other than one preliminary attempt to describe generic subsystems (Alter, 2013a) noted in Appendix 1, I am not aware of past attempts to explore, develop, or use an approach similar to facets of work within SA\&D methods or practices or related parts of the IS discipline.

Next steps. This conceptual contribution proposed that facets of work could be useful in many areas where existing knowledge is not applied in an organized and prominent way. An obvious next step is to incorporate facets of work into empirical research related to SA\&D, BPM, or EM to assess the ways in which those ideas might or might not help analysts and stakeholders. Another next step is to test the value of facets of work for practitioners. This could be done using templates or other tools that could support the type of process that was mentioned, i.e., start by identifying several facets of work that might be relevant to a specific situation, use content related to Tables A3, A4, A5, and A6 (and possibly other knowledge) to help in exploring those facets, and continue flexibly to other facets if that seems useful in the situation. Yet another next step might apply a facet-oriented classification scheme to organize published empirical research in a way that would improve visibility and accessibility of real-world experience that could provide insights for researchers or instructors.

Facets of work is new idea that addresses important disconnects in IS research and practice. Results and insights from a great deal of valuable research are not organized in a way that facilitates their use in research or in practice. This paper's main goals involved presenting the idea of facets of work, demonstrating its relevance to examples, and providing enough detail to support an appreciation of possible applications of the facets of work in tools and methods and in research. Tables and figures in the body of the paper and in the Appendix should suffice for visualizing whether the overall approach makes sense and is worth pursuing further. It is certainly possible to explore questions such as whether the 18 facets could be replaced by a better set of facets and whether a more "scientific" way to select and justify a set of facets would be preferable. The more important issue is whether organized packaging of ideas related to some version of the facets of work could support practice and research by making existing knowledge more accessible and hence more valuable. 


\section{References}

Alter, S. (2003). 18 reasons why IT-reliant work systems should replace the IT artifact as the core subject matter of the IS field. Communications of the Association for Information Systems, 12(23), 365-394.

Alter, S. (2005). Architecture of Sysperanto: A model-based ontology of the IS field. Communications of the Association for Information Systems, 15(1), 1-40.

Alter, S. (2006). The Work System Method: Connecting people, processes, and IT for business results. Larkspur, CA: Work System Press.

Alter, S. (2008). Defining information systems as work systems: Implications for the IS field. European Journal of Information Systems, 17(5), 448-469.

Alter, S. (2013a). Incorporating more system-related knowledge into systems analysis and design, Americas Conference on Information Systems, 2013.

Alter, S. (2013b). Work System Theory: Overview of Core Concepts, Extensions, and Challenges for the Future, Journal of the Association for Information Systems, 14, 72-121

Alter, S. (2015). Work System Theory as a Platform: Response to a Research Perspective Article by Niederman and March." Journal of the Association for Information Systems, 16(6), 485-514.

Alter, S. (2019). "How Could Systems Analysis Use the Idea of 'Responsible Information System'?" Information Systems Engineering in Responsible Information Systems, C. Cappiello and M. Ruiz (eds.), LNBIP 350, Springer Nature Switzerland, pp. 23-35, June 2019.

Alter, S. (2020a). "Applying Facets of Work as a Source of Knowledge and Insight for Requirements Determination," Presented in an online session in the 25th International Conference on Exploring Modeling Methods for Systems Analysis and Development (EMMSAD), June 8, 2020

Alter, S. (2020b). "How Facets of Work Illuminate Sociotechnical Challenges of Industry 5.0," Proceedings of European Conference on Information Systems, June. 2020.

Alter, S. (2020c). The Philosopher's Corner: Taking Different Types of Knowledge Objects Seriously: A Step toward Generating Greater Value from IS Research. ACM SIGMIS Database: the DATABASE for Advances in Information Systems, 51(4), 123-138.

Alter, S. (2020d). "Using Work System Theory, Facets of Work, and Dimensions of Smartness to Characterize Applications and Impacts of Al", Part I of Proceedings of IFIP WG 8.6 International Conference on Transfer and Diffusion of IT, TDIT 2020, Tiruchirappalli, India, Dec.18-19, 2020,

Alter, S. (2021). "An Open-Ended Work System Knowledge Model for Visualizing, Organizing, and Accessing Knowledge about Information Systems in Organizational Settings," Proceedings of Hawaii International Conference on Systems Science, HICSS, Jan. 2021

Alter, S., \& Bork, D. (2019). Work System Modeling Method with Different Levels of Specificity and Rigor for Different Stakeholder Purposes. Proceedings of Wirtschaftsinformatik, 2019, Siegen, Germany.

Alter, S., \& Recker, J. C. (2017). Using a work system perspective to expand BPM use cases for research. Journal of Information Technology Theory and Application, 18(1), 47-71.

Beck, K., M. Beedle, A. van Bennekum, A. Cockburn, W. Cunningham, M. Fowler, J. Greening, et al. (2001). Manifesto for agile software development, (2001). Manifesto for agile software development, URL: http://agilemanifesto.org/, (viewed on 1/22/2021)

Bērziša, S., Bravos, G., Gonzalez, T., Czubayko, U., España, S., Grabis, J., Henkel, M., et al., (2015). Capability Driven Development: an approach to designing digital enterprises. Business \& Information Systems Engineering. 57(1), 15-25.

Bolsinger, M., Elsäßer, A., Helm, C., \& Röglinger, M. (2015). Process improvement through economically driven routing of instances. Business Process Management Journal, 21(2), 353-378.

Bork, D. \& Alter, S. (2020). Satisfying Four Requirements for More Flexible Modeling Methods: Theory and Test Case. Enterprise Modelling and Information Systems Architectures., 15(3), pp. 1-25.

Broughton, V. (2006). The need for a faceted classification as the basis of all methods of information retrieval, In Aslib proceedings (Vol. 58, No. 1/2, pp. 49-72). Emerald Group Publishing Limited. 
Burton-Jones, A. , Recker, J., Indulska, M., Green, P. ,\& Weber, R. (2017) Assessing Representation Theory with a Framework for Pursuing Success and Failure. MIS Quarterly, 41(4), 1307-1333.

Checkland, P. (2000). Soft systems methodology: a thirty year retrospective, Systems research and behavioral science, 17(S1), S11-S58.

Demlehner, Q., \& Laumer, S. (2019). Setting the Hook-The Digital Transformation from a Manufacturing Point of View and what it Really Means. Proceedings of AMCIS 2019.

Engeström, Y. (1990). Developmental work research as activity theory in practice: analyzing the work of general practitioners, Y. Engeström, Learning, Working and imaging: Twelve studies in activity theory, Orienta-Konsultit OY, Helsinki.

Falkenberg, E.D., W. Hesse, and A. Olive (1995) Information System Concepts: Towards a consolidation of views, Proceedings of the IFIP International Working Conference on Information System Concepts, Marburg, Germany, March 28-30. London: Chapman \& Hall.

Falkenberg, E., Hesse, W., Lindgreen, P., Nilsson, B., Oei, H., Rolland, C., Stamper, R., Van Assche, F., Verrijn-Stuart, A. and Voss, K. (1998). A framework of information system concepts. International Federation for Information Processing.

Ferstl, O.K. \& Sinz, E.J. (2013). Grundlagen der Wirtschaftsinformatik. Oldenbourg, München.

Fettke, P. (2009). How Conceptual Modeling Is Used, Communications of the Association for Information Systems, 25, 571-592

Frank U. (2014). Multi-perspective enterprise modeling: foundational concepts, prospects and future research challenges. Software \& Systems Modeling, 13(3), 941-962.

Gawande, A. (2010). Checklist manifesto: how to get things done right, Picador, NY, NY.

Gawande, A. (2018). Why Doctors Hate Their Computers, New Yorker, Nov. 12.

Haisjackl, C., Soffer, P., Lim, S. Y., \& Weber, B. (2018). How do humans inspect BPMN models: an exploratory study. Software \& Systems Modeling, 17(2), 655-673.

Hassan, N.R., \& Mathiassen, L. (2018) Distilling a body of knowledge for information systems development, Information Systems Journal, 28(1), 175-226.

Hesse, W. \& Verrijn-Stuart, A.A. (02001). Towards a theory of information systems: the FRISCO approach. In: Kangassalo, H., et al. (eds.) Information Modelling and Knowledge Bases XII, pp. 81-91. IOS Press, Amsterdam.

Hinkel, G., Kramer, M., Burger, E., Strittmatter, M., \& Happe, L. (2016). An empirical study on the perception of metamodel quality. In 2016 4th International Conference on Model-Driven Engineering and Software Development (MODELSWARD) (145-152). IEEE

Hirschheim, R., \& Klein, H. K. (2003). Crisis in the IS field? A critical reflection on the state of the discipline. Journal of the Association for Information Systems, 4(5), 237-293.

Hudon, M., 2019. Facet. ISKO Encyclopedia of Knowledge Organization.

Johannsen, F., Leist, S., \& Braunnagel, D. (2014). Testing the impact of wand and weber's decomposition model on process model understandability. Proceedings of ICIS 2014.

Kajonius, P. J., \& Johnson, J. (2018). Sex differences in 30 facets of the five factor model of personality in the large public $(\mathrm{N}=320,128)$. Personality and Individual Differences, 129, 126-130.

Karagiannis, D. (2015). Agile modeling method engineering, In: Karanikolas, N.N., Demosthenes, A., Mara, N., Vergados, D., and Michalis, X. (eds.) Proceedings of the 19th Panhellenic Conference on Informatics - PCl'15. 5-10. ACM Press, Athens, Greece

Karagiannis, D. \& Kühn, H. (2002). Metamodelling Platforms, Third International Conference EC-Web 2002 - Dexa 2002 Bauknecht K., Min Tjoa A., Quirchmayr G. (eds.) LNCS2455 Springer, Aix-en-Provence, France, p. 182

Kendall, J.E. \& Kendall, K.E. (1993) Metaphors and Methodologies: Living Beyond the Systems Machine, MIS Quarterly, 17(2), 37-47. 
Larsen, K.R. \& Bong, C.H. (2016). A Tool for Addressing Construct Identity in Literature Reviews and Meta-Analyses," MIS Quarterly, 40(3), 529-551.

Larsen, K. R. \& Eargle, D. (Eds.) (2018) Theories Used in IS Research Wiki, at http://IS. Theorizelt.org.

Leavitt, H. J. (1964) Applied organization change in industry: structural, technical, and human approaches. In New Perspectives in Organizational Research (Cooper, S., Leavitt, H. J. and Shelly, K., Eds.), pp. 55-71, Wiley, Chichester.

Loucopoulos, P., \& Kavakli, E. (2016.) Capability oriented enterprise knowledge modeling: the CODEK approach. In Domain-Specific Conceptual Modeling, 197-215. Springer, Cham.

Mendling, J., Reijers, H. A., \& van der Aalst, W. M. (2010). Seven process modeling guidelines (7PMG). Information and Software Technology, 52(2), 127-136.

Mendling, J., Recker, J., Reijers, H. A., \& Leopold, H. (2018). An empirical review of the connection between model viewer characteristics and the comprehension of conceptual process models. Information Systems Frontiers, 1-25

Morgan, G. (1986) Images of Organization. Sage, Thousand Oaks, CA, USA.

Oates, B. J. \& Fitzgerald, B. (2007) Multi-metaphor method: organizational metaphors in information systems development, Information Systems Journal, 17, 421-339.

Opdahl, A.L. and Sindre, G., 1997. Facet modelling: An approach to flexible and integrated conceptual modelling. Information Systems, 22(5), 291-323.

Priss, U. (2008). Facet-like structures in computer science. Axiomathes, 18(2), 243-255.

Rosemann, M. \& vom Brocke, J. (2015). The six core elements of business process management, In Handbook on business process management 1 (pp. 105-122). Springer, Berlin,

Sandkuhl, K., Fill, H. G., Hoppenbrouwers, S., Krogstie, J., Matthes, F., Opdahl, A., ... \& Winter, R. (2018). From expert discipline to common practice: a vision and research agenda for extending the reach of enterprise modeling. Business \& Information Systems Engineering, 60(1), 69-80.

Simões, D., Antunes, P., \& Carriço, L. (2018). Eliciting and modeling business process stories. Business \& Information Systems Engineering, 60(2), 115-132

Stirna, J., \& Persson, A. (2018). Enterprise Modeling: Facilitating the Process and the People, Springer: Cham.

Truex, D., Alter, S., \& Long, C. (2010). Systems analysis for everyone else: Empowering business professionals through a systems analysis method that fits their needs. Proceedings of 18th European Conference on Information Systems.

Truex, D., Lakew, N., Alter, S., \& Sarkar, S. (2011). Extending a systems analysis method for business professionals. European Design Science Symposium, Leixlip, Ireland.

van der Aalst, W.M.P (2012). What makes a good process model? Software \& Systems Modeling,11, 557569.

van der Aalst, W. M. P. (2013). Business process management: A comprehensive survey, ISRN Software Engineering, 1-37.

Vargo, S. L., \& Lusch, R. F., (2016). Institutions and axioms: an extension and update of service-dominant logic, Journal of the Academy of Marketing Science, 44(1), 5-23.

Vial, G. (2019). Understanding digital transformation: A review and a research agenda. The Journal of Strategic Information Systems, 28(2), 118-14

vom Brocke, J., \& Sinnl, T. (2011). Culture in business process management: a literature review, Business Process Management Journal, 17(2), 357-378.

Wand, Y. \& Weber, R. (1990) Towards a Theory of the Deep Structure of Information Systems," Proceedings of ICIS 1990.

Wild, P. J., Giess, M. D., \& McMahon, C. A. (2009). Describing engineering documents with faceted approaches. Journal of Documentation. 65 (3), 420-445. 
Winter, M. \& Szczepanek, T. (2009) Images of Projects. Farnham, England: Gower Publishing Ltd. 


\section{Appendix 1: Background and Related Literature}

This section summarizes the somewhat disconnected steps that led to the current version of the facets of work. It also mentions some of the other uses of the term facet that appear in research in other fields. This section was placed in an Appendix in order to make the discussion of the background more understandable and because the false starts and obstacles encountered as the ideas developed might not matter to many readers.

The idea of facets of work was developed as one of many extensions of work system theory (WST) but is useful regardless of whether WST is being used, as was shown by the three examples in Section 3 and the proposed applications in Section 5. The development of facets of work as an extension of WST that tried to address a long-standing shortcoming of the work system method (WSM) led to a quandary about how to explain the development of the ideas. On the one hand, most research publications are expected to explain the motivation for research efforts and the provenance and development of ideas that are used or developed. On the other hand, repeating discussions of WST, WSM, and related ideas that have been presented many times (e.g., Alter, 2003; 2008, 2013, 2015) seems redundant, especially since the facets of work can be used independent of WST and WSM.

The compromise pursued here started with using several paragraphs in the introduction to establish the paper's motivation by discussing a desire to improve management briefings produced by MBA and EMBA students whose use of work system ideas was largely implied rather than discussed in detail. This Appendix continues from that point, identifies issues that became clearer during several intermediate efforts that did not meet their own goals, and finally summarizes how the idea of facets of work emerged in subsequent research.

Trying to extend WST. The idea of facets of work is an extension of work system theory (WST) that was developed to address a major gap that was not articulated clearly until the idea of facets of work was developed recently. The gap was that WST did not differentiate adequately between activities of different types even though it highlighted work systems that necessarily included activities of many types. The content of numerous management briefings produced by MBA and Executive MBA students hinted at the desirability of producing a WST extension that somehow might help them produce more interesting and insightful recommendations.

A prematurely ambitious proposal (Alter, 2005) suggested a possible architecture for an ontology of IS that was named Sysperanto, a play on the purported universal language Esperanto. The proposed ontology tried to build on results of a series of ISCO (Information Systems Concepts) conferences sponsored by IFIP 8.1 in 1989, 1992,1995, and 1999. Those conferences attempted to identify the basic concepts of IS, but ultimately produced reports (Falkenberg et al, 1995; Falkenberg et al, 1998; Hesse \& Verrijn-Stuart, 2001) that were less than satisfying to many of the main participants in the effort. The architecture of Sysperanto was organized around the elements of the work system framework and the assumption that information systems, projects, supply chains, e-commerce, and many other important types of systems can be modeled as work systems. That assumption remains as the basis of the current work system perspective, whose core consists of the three components of WST: the definition of work system, the work system framework (the triangular framework in Figure 3, minus the facets), and the work system life cycle model, which is not shown here. The work system perspective builds on WST by including extensions and use cases. The extensions include WS axioms, WS design principles, a theory of workarounds, a system interaction theory, a set of WS metamodels, and ideas about the inheritance of WS properties by special cases such as information systems. The use cases include the work system method (Alter, 2006), a related SA\&D toolkit, and applications of WST and its extensions for understanding many topics in the IS discipline.

While basic assumptions underlying Sysperanto remained, its architecture included the awkward idea of a "slice" that tried to build on the way "people understand business and organizational reality by slicing it in a variety of ways. In Sysperanto a "slice" ... is a related set of properties that can be applied when trying to understand or analyze a particular work system. Although slices may overlap, each slice provides a particular set of concepts, associations, and understandings." (Alter, 2005, p. 11). The idea of slices was not developed further at that time, but turned out to be a precursor of the idea of facets explained here.

A subsequent effort (Alter, 2013a) was inspired by earlier publications that applied metaphors for understanding complex management or system topics (e.g., Morgan, 1986; Kendall and Kendall, 1993; Oates and Fitzgerald, 2007; Winter and Szczepanek, 2009). That effort identified 8 subsystem types such as decision subsystem and communication subsystem (rather than typical categories such as ICT, MIS, or 
DSS), each of which suggested potentially useful metaphors that might provide insights in SA\&D. The subsystem approach proved limited because subsystems are typically viewed as being contiguous, whereas activities related to decision making and communication may not be contiguous within a system, e.g., decision making might be important in steps 2, 3, and 9 of a process, but not in steps 4 through 8 .

A third effort from the domain of enterprise and process modeling (Alter and Bork, 2019; Bork and Alter, 2020) focused on a different set of problems but eventually led to an insight about facets of work. That effort suggested ways to "relax" some of the formal requirements on enterprise and process modeling suggested by Karagiannis and Kühn (2002). It was inspired by researchers from various backgrounds noting frequently that modelling methods related to processes and enterprises need to be extended or augmented to make them more usable by broader user groups and for broader purposes (e.g., Sandkuhl et al., 2018; van der Aalst, 2012; Karagiannis, 2015). The idea of a two dimensional design space for modeling methods (Alter and Bork, 2019, p. 6) came from reviewing research on modelling method usage (e.g., Fettke, 2009; Mendling et al. 2010), model comprehension (e.g., Haisjackl et al., 2018; Johannsen et al., 2014; Mendling et al., 2018), and misfit between modeling methods and modelers' aptitudes, knowledge, and purposes (e.g., Hinkel et al., 2016; Simões et al., 2018). That design space suggested that different user purposes (e.g., identifying systems, describing capabilities, describing system scope and operation, etc.) call for models with different degrees of rigor and specificity organized around a single "overarching modelling metaphor" (Ferstl and Sinz 2013), which was the idea of work system in that research.

The "user purpose" of describing capabilities initially came from awareness of capability-driven development (Bērziša et al., 2015; Loucopoulos \& Kavakli, 2016). Trying to express capability-related ideas within a work system metaphor led to consideration of multiple facets of capabilities. Thinking about that topic led to recalling previous attempts to apply system-related metaphors in SA\&D, and that inspired the possibility of using the idea of facets of work as a path toward achieving unmet goals of the earlier research. The iterative process of identifying the current 18 facets of work started by renaming the subsystem types from Alter (2013a) as a set of capabilities in Alter (2019). Within a work system perspective those ideas could be presented more naturally as facets of work rather than facets of capabilities.

Faceted organization of knowledge. The idea of facet has been used with quite different meanings and connotations in psychology, library science, information science, computer science, and other disciplines. Preliminary literature searches identified uses of facet that will be mentioned here for the sake of completeness even though they did not provide insights for this paper's use of that idea.

In psychology, each factor in the widely used five-factor model of personality (neuroticism, extraversion, openness, agreeableness, conscientiousness) has been expanded into six facets. For example, facets of conscientiousness include self-efficacy, orderliness, dutifulness, achievement, self-discipline, and cautiousness (e.g., Kajonius \& Johnson, 2018). In library science, Ranganathan introduced the term facet in a series of books in the mid-1900s. A lengthy article (Hudon, 2019) in the Library of Knowledge Organization notes that facet became somewhat of a buzzword in knowledge organization, knowledge management, and information architecture. Broughton (2006) says that "faceted classification in some form or another now plays an integral part in most methods of information retrieval." Nonetheless, observers such as Wild et al. (2009) note theoretical and practical issues such as "differing interpretations of the facet notion; confusion between faceted analysis and faceted classification; lack of methodological guidance; the use of simplistic domains as exemplars, and so on."

A paper on facet-like structures in computer science identifies the following facet-like structures: facet, database field, view (table), class, aspect, scale, situation, context, and channel (Priss, 2008). In facet modeling, "facets are intended to represent numerous and highly diverse kinds of aspects, ranging from the informal to the formal, from the soft to the hard, from the general to the special, from the whole to the parts, etc." (Opdahl and Sindre, 1997, p. 302). Those kinds of aspects apply to the use of facets in visualizing and analyzing work systems. Importantly, since the work system perspective is meant to provide guidance without imposing too much structure on users, the use of facets in conjunction with work systems does not need to satisfy Opdahl \& Sindre's expectations of rigorous facet modeling, such as a "powerful and flexible mechanism to accurately specify the structure and content types of a particular kind of facets" (p. 302) as in programming languages.

In contrast with past uses of the term facet, this paper uses that idea as a way to address the major limitation of WST that has been mentioned several times. WST and its previous extensions did not link directly to a great deal of knowledge about frequently relevant topics such as decision making, communication, and coordination. Articulating facets of work as a new extension of WST appears to be a new path for relating a 
great deal of existing knowledge more directly to the operation of systems in organizations. Strengthening that relationship could help business stakeholders and technical experts as they try to visualize, describe, and analyze those systems.

\section{Appendix 2: Tables Showing Knowledge Related to Facets of Work}

The following six tables contain ideas that are potentially valuable for SA\&D and other purposes. They appear in the Appendix because their appearance earlier would have made this paper's main narrative choppy and difficult to follow.

- Table A1 summarizes why all 18 facets of work are significant in many situations.

- Table A2 shows that almost all 18 facets of work apply to both sociotechnical systems and totally automated systems that operate autonomously.

- Table A3 shows that each of the 18 facets of work is associated with concepts and other knowledge that is associated more directly with that facet than with other facets.

- Table A4 shows that all 18 facets bring common evaluation criteria and design tradeoffs that can be used when analyzing, designing, or evaluating systems in organizations.

- Table A5 shows that most of the 18 facets have sub-facets that in some situations might provide guidance for looking at specific facets of work in greater depth.

- Table A6 shows that all 18 facets imply open-ended questions that can be used to start discussions related to specific facets. Those facet-specific questions build on two simple questions: 1 ) Where is this facet important for this real-world situation or research area? 2) What are important issues or opportunities related to this facet?

18 common facets of work. Table A1 provides a brief comment about the frequent importance of each of 18 facets, all of which could be the topic of a complete literature review. They also could be the topic of at least two open-ended questions at the beginning of a description or analysis process regardless of whether a version of the work system method was used:

- Where is this facet of work important in this situation?

- What are important issues or opportunities related to this facet?

Those open-ended questions could be considered a starting point, with some facets more important than others in any specific situation. Facets that seem unimportant initially could be set aside so that stakeholders could focus on the facets that seem most relevant in the current situation for a combination of description, management concerns, and speculation. Table A6 will identify typical open-ended questions that are directly related to each facet of work. 
Table A1. 18 common facets of work

\begin{tabular}{|c|c|}
\hline Facet & Importance of considering this facet \\
\hline $\begin{array}{l}\text { Making } \\
\text { decisions }\end{array}$ & $\begin{array}{l}\text { Treating decisions simply as steps in a process is often inadequate if issues and } \\
\text { opportunities related to the rationale or quality of decisions are important. }\end{array}$ \\
\hline Communicating & $\begin{array}{l}\text { Inadequate communication is a common complaint in business situations. Often the } \\
\text { problem is not about specific steps but rather about clarity, involvement, terminology, } \\
\text { and other issues. }\end{array}$ \\
\hline $\begin{array}{l}\text { Providing } \\
\text { information }\end{array}$ & $\begin{array}{l}\text { In many business situations people complain that they are not informed adequately } \\
\text { about information or situations they should know about. }\end{array}$ \\
\hline $\begin{array}{l}\text { Representing } \\
\text { reality }\end{array}$ & $\begin{array}{l}\text { Many information systems represent reality in ways that are incomplete or } \\
\text { misleading, for example by providing inadequate options for recording or coding } \\
\text { problems or incidents. }\end{array}$ \\
\hline $\begin{array}{l}\text { Applying } \\
\text { knowledge }\end{array}$ & $\begin{array}{l}\text { Significant business situations typically require the application of general and/or } \\
\text { specialized knowledge which may be tacit or explicit and codified or uncodified. }\end{array}$ \\
\hline Thinking & $\begin{array}{l}\text { While artificial intelligence and related topics receive a great deal of attention, many } \\
\text { work situations simply require ability and time to think carefully and sometimes } \\
\text { creatively. }\end{array}$ \\
\hline Learning & $\begin{array}{l}\text { Adaptations and workarounds in business activities often contribute to learning. } \\
\text { Trends toward applying Al bring new attention to methods by which machines or } \\
\text { systems might learn. }\end{array}$ \\
\hline Planning & $\begin{array}{l}\text { Inadequate planning often leads to disappointing results even though there are } \\
\text { some situations where improvisation is more important than planning. }\end{array}$ \\
\hline $\begin{array}{l}\text { Controlling } \\
\text { execution }\end{array}$ & $\begin{array}{l}\text { Controlling the execution of work often calls for finding an appropriate balance } \\
\text { between inadequate control to excessive surveillance. }\end{array}$ \\
\hline Coordinating & $\begin{array}{l}\text { Efficient and effective operation of an organizatio } \\
\text { people and groups performing related tasks and/or }\end{array}$ \\
\hline Improvising & $\begin{array}{l}\text { Understanding the reality of how work is performed in many settings requires } \\
\text { considering improvisations and workarounds that occur when work is relatively } \\
\text { unstructured and when exceptions and other conditions require deviation from } \\
\text { established practices. }\end{array}$ \\
\hline $\begin{array}{l}\text { Processing } \\
\text { information }\end{array}$ & $\begin{array}{l}\text { Most business situations involve some form of information processing by people } \\
\text { and/or machines. Digitalization increases reliance on information processing by } \\
\text { machines. }\end{array}$ \\
\hline $\begin{array}{l}\text { Performing } \\
\text { physical work }\end{array}$ & $\begin{array}{l}\text { Trends toward digitalization coexist with the continuing importance of creating, } \\
\text { modifying, moving, or adjusting physical things. }\end{array}$ \\
\hline $\begin{array}{l}\text { Performing } \\
\text { support work }\end{array}$ & $\begin{array}{l}\text { Process documentation often does not include support work (also called articulation } \\
\text { work) that helps in coordinating documented work steps, overcoming transient } \\
\text { obstacles, and obtaining needed resources in a timely manner. }\end{array}$ \\
\hline $\begin{array}{l}\text { Interacting } \\
\text { socially }\end{array}$ & $\begin{array}{l}\text { Inadequate social interaction may degrade work performance by lessening } \\
\text { cooperation, whereas excessive social interaction may generate inefficiencies such } \\
\text { as absorbing too much time. }\end{array}$ \\
\hline $\begin{array}{l}\text { Providing } \\
\text { service }\end{array}$ & $\begin{array}{l}\text { The purpose of most work activities is to produce things, actions, or conditions that } \\
\text { facilitate benefits for others, implying that considering service aspects is often } \\
\text { important. }\end{array}$ \\
\hline Creating value & $\begin{array}{l}\text { Direct attention to value is important because attempts to produce things for others } \\
\text { or with others (e.g., value co-creation) does not guarantee that value is created } \\
\text { either for intended beneficiaries or people or organizations that perform the work. }\end{array}$ \\
\hline $\begin{array}{l}\text { Maintaining } \\
\text { security }\end{array}$ & $\begin{array}{l}\text { Many threats have emerged related to access and transmission of inadequately } \\
\text { guarded digital information. Privacy concerns compound those issues. }\end{array}$ \\
\hline
\end{tabular}

Relevance to sociotechnical and totally automated systems. Table A2 shows that facets of work apply to both sociotechnical work systems and totally automated work systems. In sociotechnical systems, human participants perform at least some of the activities that produce product/services for customers. In contrast, machines typically under the control of software perform all of the work in totally automated systems. Relevance of the facets of work to both sociotechnical and totally automated systems is increasingly important as digitalization and automation play increasingly important roles in business and society. Note that the people who create and maintain automated systems perform that work in other work systems that are devoted to creating and maintaining the automated systems. 
Table A2. Relevance of facets of work to both sociotechnical and totally automated systems

\begin{tabular}{|c|c|c|}
\hline Facet & $\begin{array}{l}\text { Sociotechnical work performed } \\
\text { by people }\end{array}$ & $\begin{array}{l}\text { Automated work performed by } \\
\text { machines controlled by software }\end{array}$ \\
\hline $\begin{array}{l}\text { Making } \\
\text { decisions }\end{array}$ & $\begin{array}{l}\text { People use information that supports } \\
\text { a decision process. } \\
\text { Example: Marketing manager } \\
\text { decides on allocation of advertising } \\
\text { budget. }\end{array}$ & $\begin{array}{l}\text { Computer uses software algorithms to } \\
\text { make decisions automatically. } \\
\text { Example: A marketing model calculates } \\
\text { automatic allocation of advertising budget. }\end{array}$ \\
\hline Communicating & $\begin{array}{l}\text { People communicate with other } \\
\text { people as part of collaboration. } \\
\text { Example: Sales managers meet to } \\
\text { discuss issues, problems, and } \\
\text { tradeoff's. }\end{array}$ & $\begin{array}{l}\text { Computer communicates an alert to } \\
\text { human users. } \\
\text { Example: A computer creates a message } \\
\text { highlighting last week's key performance } \\
\text { gaps. }\end{array}$ \\
\hline $\begin{array}{l}\text { Providing } \\
\text { information }\end{array}$ & $\begin{array}{l}\text { People provide information upon } \\
\text { request or on a periodic basis. } \\
\text { Example: An employee submits a } \\
\text { progress report before meeting with } \\
\text { manager }\end{array}$ & $\begin{array}{l}\text { A computer provides information, either by } \\
\text { subscription or on demand. } \\
\text { Example: An internet-based news service } \\
\text { provides a customized daily newspaper. }\end{array}$ \\
\hline $\begin{array}{l}\text { Representing } \\
\text { reality }\end{array}$ & $\begin{array}{l}\text { People create a representation of } \\
\text { reality. } \\
\text { Example: Accountants perform } \\
\text { financial analysis and create } \\
\text { financial reports. }\end{array}$ & $\begin{array}{l}\text { A computer uses software and data to } \\
\text { create a representation of reality. } \\
\text { Example: A facial recognition system } \\
\text { identifies people in a location. }\end{array}$ \\
\hline $\begin{array}{l}\text { Applying } \\
\text { knowledge }\end{array}$ & $\begin{array}{l}\text { People use expert knowledge to } \\
\text { perform a complex diagnosis. } \\
\text { Example: A physician determines } \\
\text { that a patient has an unusual } \\
\text { medical problem. }\end{array}$ & $\begin{array}{l}\text { A computer uses a neural network to } \\
\text { perform a complex diagnosis task. } \\
\text { Example: A computer uses thousands of } \\
\text { cases to create a neural network that is } \\
\text { used to identify a patient's problem. }\end{array}$ \\
\hline Thinking & $\begin{array}{l}\text { People think about a situation, } \\
\text { decide what is important, and make } \\
\text { decisions. } \\
\text { Example: A doctor considers } \\
\text { medical evidence and decides what } \\
\text { to prescribe. }\end{array}$ & $\begin{array}{l}\text { A computer analyses the same situation } \\
\text { and uses an algorithm to suggest an } \\
\text { approach. } \\
\text { Example: A computer uses an algorithm to } \\
\text { consider evidence and decides what to } \\
\text { prescribe. }\end{array}$ \\
\hline Learning & $\begin{array}{l}\text { Human workers learn as they } \\
\text { perform their work. } \\
\text { Example: A manager learns by } \\
\text { experience about what is effective. }\end{array}$ & $\begin{array}{l}\text { A computerized tool identifies changing } \\
\text { conditions and adjusts accordingly. } \\
\text { Example: A computer adjusts a trading } \\
\text { algorithm based on changes in a market. }\end{array}$ \\
\hline Planning & $\begin{array}{l}\text { People use information and } \\
\text { knowledge to create plans. } \\
\text { Example: A manager plans factory } \\
\text { production to satisfy existing orders. }\end{array}$ & $\begin{array}{l}\text { A computer uses information and } \\
\text { algorithms to create plans. } \\
\text { Example: A computerized algorithm plans } \\
\text { factory production for current orders. }\end{array}$ \\
\hline $\begin{array}{l}\text { Controlling } \\
\text { execution }\end{array}$ & $\begin{array}{l}\text { Managers use information and } \\
\text { incentives to motivate employees. } \\
\text { Example: Daily incentives push } \\
\text { employees to meet daily goals. }\end{array}$ & $\begin{array}{l}\text { A computer uses business rules to control } \\
\text { execution of processes. } \\
\text { Example: BPM software enables the next } \\
\text { step after a previous step completes. }\end{array}$ \\
\hline Coordinating & $\begin{array}{l}\text { People coordinate activities and } \\
\text { resource use for mutual benefit. } \\
\text { Example: Two teams coordinate } \\
\text { work to share resources needed by } \\
\text { both. }\end{array}$ & $\begin{array}{l}\text { Computers use algorithms to coordinate } \\
\text { activities and resource use. } \\
\text { Example: Two autonomous machines } \\
\text { take turns using a resource needed by } \\
\text { both. }\end{array}$ \\
\hline Improvising & $\begin{array}{l}\text { People decide how to proceed } \\
\text { based on intuition and resources } \\
\text { that are available in the situation } \\
\text { facing them. } \\
\text { Example: A police team responds to } \\
\text { an unfolding public safety threat. }\end{array}$ & $\begin{array}{l}\text { A computer decides how to proceed based } \\
\text { on search algorithms and a representation } \\
\text { of the current reality. } \\
\text { Example: An autonomous vehicle } \\
\text { identifies and avoids obstacles. }\end{array}$ \\
\hline
\end{tabular}




\begin{tabular}{|c|c|c|}
\hline $\begin{array}{l}\text { Processing } \\
\text { information }\end{array}$ & $\begin{array}{l}\text { People capture, transmit, store, } \\
\text { delete, retrieve, display, or } \\
\text { manipulate data. } \\
\text { Example: A researcher collects, } \\
\text { filters, and summarizes information. }\end{array}$ & $\begin{array}{l}\text { Computer or other device captures, } \\
\text { transmits, stores, deletes, retrieves, } \\
\text { displays, or manipulates data. } \\
\text { Example: information processing via RFID } \\
\text { system, MRI system, or digital camera }\end{array}$ \\
\hline $\begin{array}{l}\text { Performing } \\
\text { physical work }\end{array}$ & $\begin{array}{l}\text { People perform physical activities } \\
\text { beyond processing information. } \\
\text { Example: People move packages } \\
\text { from one location to another. }\end{array}$ & $\begin{array}{l}\text { Machines perform physical activities } \\
\text { beyond processing information. } \\
\text { Example: Machines move packages from } \\
\text { one location to another. }\end{array}$ \\
\hline $\begin{array}{l}\text { Performing } \\
\text { support work }\end{array}$ & $\begin{array}{l}\text { People assure that others have } \\
\text { resources they need to perform their } \\
\text { work. } \\
\text { Example: Support staff assures that } \\
\text { computers are working properly. }\end{array}$ & $\begin{array}{l}\text { Automated linkages assure that people } \\
\text { have resources they need to perform their } \\
\text { work. } \\
\text { Example: Automated update services } \\
\text { assure that users' software is up to date. }\end{array}$ \\
\hline $\begin{array}{l}\text { Interacting } \\
\text { socially }\end{array}$ & $\begin{array}{l}\text { People enact everyday social } \\
\text { relations while participating in } \\
\text { organizations. } \\
\text { Example: People chat during work } \\
\text { breaks or during meetings. }\end{array}$ & $\begin{array}{l}\text { Interacting socially does not describe how } \\
\text { current machines operate. At some point } \\
\text { "social-like" interactions might help } \\
\text { machines coordinate within or between } \\
\text { enterprises. }\end{array}$ \\
\hline $\begin{array}{l}\text { Providing } \\
\text { service }\end{array}$ & $\begin{array}{l}\text { People perform activities for the } \\
\text { benefit of others. } \\
\text { Example: "Super-users" help others } \\
\text { understand software features. }\end{array}$ & $\begin{array}{l}\text { Machines perform activities that respond to } \\
\text { a user request. } \\
\text { Example: A computer uses a search } \\
\text { algorithm to compile search results. }\end{array}$ \\
\hline Creating value & $\begin{array}{l}\text { People produce product/services } \\
\text { that matter to customers or users. } \\
\text { Example: An artist produces a } \\
\text { painting that a buyer values. }\end{array}$ & $\begin{array}{l}\text { Machines produce product/services that } \\
\text { matter to customers or users. } \\
\text { Example: An automated alarm system } \\
\text { produces a feeling of safety. }\end{array}$ \\
\hline $\begin{array}{l}\text { Maintaining } \\
\text { security }\end{array}$ & $\begin{array}{l}\text { Undisciplined computer usage } \\
\text { generates opportunities for crime. } \\
\text { Example: A firm trains its employees } \\
\text { to recognize data security threats. }\end{array}$ & $\begin{array}{l}\text { Computerized systems enforce data } \\
\text { standards and access restrictions } \\
\text { Example: Digital rights management } \\
\text { (DRM) systems restrict access based on } \\
\text { role-related access rights. }\end{array}$ \\
\hline
\end{tabular}

Concepts related to each facet of work. Table A3 identifies common concepts related to the 18 facets. The key point here is that many of those terms are only tangentially associated with established techniques of SA\&D, BPM, and EM even though the facets often could provide important clues for requirements determination. Literature reviews for each facet would find that many concepts and generalizations related to each facet have been articulated and researched in great depth.

Table A3. Common concepts related to each facet of work

\begin{tabular}{|l|l|}
\hline \multicolumn{1}{|c|}{ Facet } & \multicolumn{1}{|c|}{ Related concepts } \\
\hline $\begin{array}{l}\text { Making } \\
\text { decisions }\end{array}$ & $\begin{array}{l}\text { Decision, decision criteria, alternative, value, risk, payoff, utility, utility function, } \\
\text { tradeoff, projection, optimum, satisficing vs. optimizing, heuristic, probability, } \\
\text { distribution of results, risk aversion }\end{array}$ \\
\hline Communicating & $\begin{array}{l}\text { Comprehension, one-way vs. two-way, messages, utterances, encoding, transmitting, } \\
\text { decoding, interpreting, communication channel, media, media richness, wired, } \\
\text { wireless, signal-to-noise ratio, attenuation }\end{array}$ \\
\hline $\begin{array}{l}\text { Providing } \\
\text { information }\end{array}$ & $\begin{array}{l}\text { Inclusion, exclusion, accuracy, conciseness, focus, filtering, outlining, textual vs. } \\
\text { graphical presentation, types of graphical displays, personal style related to } \\
\text { information usage, information deficiency, information overload }\end{array}$ \\
\hline $\begin{array}{l}\text { Representing } \\
\text { reality }\end{array}$ & $\begin{array}{l}\text { Entity, event, state, inclusion, exclusion, filtering, summarization, precision, bias, } \\
\text { characteristic, measure of performance }\end{array}$ \\
\hline $\begin{array}{l}\text { Applying } \\
\text { knowledge }\end{array}$ & $\begin{array}{l}\text { Tacit vs. explicit knowledge, codified vs. noncodified knowledge, domain of } \\
\text { knowledge, know-how, rules of thumb, knowledge base, neural network, expert } \\
\text { system, cognitive computing, artificial intelligence }\end{array}$ \\
\hline
\end{tabular}




\begin{tabular}{|c|c|}
\hline Thinking & $\begin{array}{l}\text { Thoughts, concepts, images, perceptions, memories, recall, awareness, } \\
\text { consciousness, reasoning, realizations, imagination }\end{array}$ \\
\hline Learning & $\begin{array}{l}\text { Learning curve, retention, forgetting, skills, experimenting, observing, practicing, } \\
\text { assimilating, experiential learning, rote learning, active learning, testing }\end{array}$ \\
\hline Planning & $\begin{array}{l}\text { Plan, feasibility, needs, goals, forecasts, resources, dependencies, capacity, slack } \\
\text { resources, planned resource utilization, strategic vs. tactical vs. operational planning, } \\
\text { rational choice, planned capacity utilization, planned fulfillment, planned versus actual } \\
\text { results }\end{array}$ \\
\hline $\begin{array}{l}\text { Controlling } \\
\text { execution }\end{array}$ & $\begin{array}{l}\text { Goal, evaluation method, evaluation criteria, positive and negative feedback, } \\
\text { standardization, rationale, business rules, chaotic behavior, informal vs. formal } \\
\text { feedback }\end{array}$ \\
\hline Coordinating & $\begin{array}{l}\text { Managing dependencies, interdependent tasks, coordination mechanisms, } \\
\text { synchronization, alignment, standardization, bidding, assigning resources }\end{array}$ \\
\hline Improvising & $\begin{array}{l}\text { Resources at hand, bricolage, adaptation, workaround, trial and error, merger of } \\
\text { thinking and acting, extemporaneous action }\end{array}$ \\
\hline $\begin{array}{l}\text { Processing } \\
\text { information }\end{array}$ & $\begin{array}{l}\text { [nouns] entity, relationship, data item, class, method, object, event, state, process, } \\
\text { pre-condition, post-condition, business rules, } \\
\text { [verbs] capture, transmit, store, retrieve, delete, manipulate, display, initialize, initiate, } \\
\text { update, back-up, restore, roll back }\end{array}$ \\
\hline $\begin{array}{l}\text { Performing } \\
\text { physical work }\end{array}$ & $\begin{array}{l}\text { Manual labor, blue collar work, ergonomics, movement, physical abilities, physical } \\
\text { stress, work environment, repetitive stress, exposure }\end{array}$ \\
\hline $\begin{array}{l}\text { Performing } \\
\text { support work }\end{array}$ & $\begin{array}{l}\text { Providing support, facilitating workflows, improvising, filling in, fixing breakdowns, } \\
\text { maintaining continuity of shared or distributed work, working to help others work }\end{array}$ \\
\hline $\begin{array}{l}\text { Interacting } \\
\text { socially }\end{array}$ & $\begin{array}{l}\text { Social relationships, groups, teams, social cohesion, trust, group membership, shared } \\
\text { culture, social conflict, virtual teams, presentation of self }\end{array}$ \\
\hline $\begin{array}{l}\text { Providing } \\
\text { service }\end{array}$ & $\begin{array}{l}\text { Service provider, service customer, service interaction, value proposition, resource } \\
\text { integration, co-production, service logic, service-dominant logic, }\end{array}$ \\
\hline Creating value & $\begin{array}{l}\text { Value, value added, economic value, value-in-use, value capture, customers creating } \\
\text { value for themselves, customers assessing value for themselves }\end{array}$ \\
\hline $\begin{array}{l}\text { Maintaining } \\
\text { security }\end{array}$ & $\begin{array}{l}\text { Vulnerability, assurance, accountability, authorization, access rights, confidentiality, } \\
\text { authenticity, trustworthiness, auditability, non-repudiation }\end{array}$ \\
\hline
\end{tabular}

Evaluation criteria and design tradeoffs related to each facet. Table A4 shows that each facet suggests typical evaluation criteria and design tradeoffs. Some of the criteria and design tradeoffs are common to many activities, processes, and systems, but others are mostly associated with specific facets. For example, cost, efficiency, and effectiveness are criteria that can be used in relation to most of the facets. In contrast, accuracy, riskiness, and social cohesion apply to specific facets and are not directly applicable to most of the others.

Table 4. Typical evaluation criteria and design trade-offs related to each facet

\begin{tabular}{|c|c|c|}
\hline Facet & Typical evaluation criteria & Typical design tradeoffs \\
\hline $\begin{array}{l}\text { Making } \\
\text { decisions }\end{array}$ & $\begin{array}{l}\text { Decision outcomes, riskiness, } \\
\text { participation, concurrence, } \\
\text { ease of implementation, } \\
\text { reliance on method or data }\end{array}$ & $\begin{array}{l}\text { - } \text { Quick responsiveness vs. superficiality. } \\
\text { - Complexity and precision of models vs. } \\
\text { understandability } \\
\text { - Brevity vs. omission of important details }\end{array}$ \\
\hline Communicating & $\begin{array}{l}\text { Clarity, understandability, } \\
\text { conciseness, accuracy of the } \\
\text { perception of a message, } \\
\text { extent of empathy and } \\
\text { warmth, signal to noise ratio }\end{array}$ & $\begin{array}{l}\text { - Insufficient vs. excessive communication } \\
\text { - Richness of multiple communication channels vs. } \\
\text { confusion about which channels to use when. } \\
\text { - Focusing on message production versus impact } \\
\text { of the communication }\end{array}$ \\
\hline $\begin{array}{l}\text { Providing } \\
\text { information }\end{array}$ & $\begin{array}{l}\text { Information quality, } \\
\text { completeness, accessibility, } \\
\text { usefulness, timeliness, } \\
\text { accuracy, understandability, } \\
\text { source, comparability, bias }\end{array}$ & $\begin{array}{l}\text { - Informing vs. under-informing or over-informing. } \\
\text { - Understandability vs. information overload } \\
\text { - Predefined information vs. ad hoc specification } \\
\text { - Focusing on informing and information transfer } \\
\text { vs. human abilities to perceive and process } \\
\text { information }\end{array}$ \\
\hline
\end{tabular}




\begin{tabular}{|c|c|c|}
\hline $\begin{array}{l}\text { Representing } \\
\text { reality }\end{array}$ & 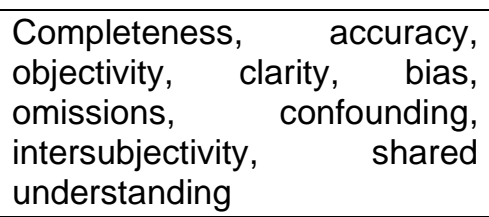 & $\begin{array}{l}\text { - Precision/ granularity vs. big picture issues and } \\
\text { understandability. } \\
\text { - Focusing on objective data that can collected } \\
\text { automatically vs. reflecting reality more fully by } \\
\text { including subjective information. }\end{array}$ \\
\hline $\begin{array}{l}\text { Applying } \\
\text { knowledge }\end{array}$ & $\begin{array}{l}\text { Accuracy of knowledge, ability } \\
\text { of discriminate between } \\
\text { cases, appropriateness of } \\
\text { application of knowledge }\end{array}$ & $\begin{array}{l}\text { - Using too little knowledge vs. waiting until more } \\
\text { knowledge can be obtained and filtered } \\
\text { - Relying on human knowledge and intuition vs. } \\
\text { relying on computerized techniques }\end{array}$ \\
\hline Thinking & $\begin{array}{l}\text { Clarity, precision, flexibility, } \\
\text { insight, originality, focus }\end{array}$ & $\begin{array}{l}\text { - Maintaining control versus freedom to think } \\
\text { - Maintaining focus vs. out-of-the-box thinking }\end{array}$ \\
\hline Learning & $\begin{array}{l}\text { Mastery of content, retention, } \\
\text { errors, confusions, rate of } \\
\text { knowledge acquisition }\end{array}$ & $\begin{array}{l}\text { - Small increments vs. large leaps } \\
\text { - Supervised vs. unsupervised learning } \\
\text { - Theoretical vs. experiential learning }\end{array}$ \\
\hline Planning & $\begin{array}{l}\text { Feasibility, alignment with } \\
\text { strategy, goal achievement, } \\
\text { planned capacity utilization, } \\
\text { actual capacity utilization }\end{array}$ & $\begin{array}{l}\text { - Under-utilization vs. allowing too little slack } \\
\text { - Predictability of outcomes vs. risk of shortfalls } \\
\text { - Inclusion vs. exclusion of possible responses to } \\
\text { known contingencies }\end{array}$ \\
\hline $\begin{array}{l}\text { Controlling } \\
\text { execution }\end{array}$ & $\begin{array}{l}\text { Extent and duration of } \\
\text { deviations from goals, delays, } \\
\text { cost of monitoring, } \\
\text { effectiveness of corrections, } \\
\text { likelihood of overshooting } \\
\text { control targets }\end{array}$ & $\begin{array}{l}\text { - Micromanagement vs. risks of non-compliance } \\
\text { - } \text { Quick responsiveness vs. instability. } \\
\text { - Focusing on control targets vs. minimizing } \\
\text { negative impacts on participants or customer }\end{array}$ \\
\hline Coordinating & $\begin{array}{l}\text { Quality of resource sharing, } \\
\text { quality of synchronization }\end{array}$ & $\begin{array}{l}\text { - Cost of coordinating vs. cost of excess resources } \\
\text { - Using rules vs. using negotiations }\end{array}$ \\
\hline Improvising & $\begin{array}{l}\text { Task accomplishment, } \\
\text { response time, resource } \\
\text { utilization }\end{array}$ & $\begin{array}{l}\text { - Quick response vs. non-compliance with norms } \\
\text { - Control vs. freedom to act }\end{array}$ \\
\hline $\begin{array}{l}\text { Processing } \\
\text { information }\end{array}$ & $\begin{array}{l}\text { Efficiency, cost, accuracy, } \\
\text { precision, error rate, rework } \\
\text { rate, downtime, vulnerability }\end{array}$ & $\begin{array}{l}\text { - Cost and efficiency vs. completeness and detail. } \\
\text { - Focusing on processing data vs. producing useful } \\
\text { information that fits task or decision needs }\end{array}$ \\
\hline $\begin{array}{l}\text { Performing } \\
\text { physical work }\end{array}$ & $\begin{array}{l}\text { Task completion, } \\
\text { conformance, speed, physical } \\
\text { stress, impact on workers, } \\
\text { workplace injuries }\end{array}$ & $\begin{array}{l}\text { - Automating tasks vs. performing tasks manually } \\
\text { - Efficiency vs. overload } \\
\text { - Considering vs. ignoring impacts on people } \\
\text { performing physical work }\end{array}$ \\
\hline $\begin{array}{l}\text { Performing } \\
\text { support work }\end{array}$ & $\begin{array}{l}\text { Continuity of supported work, } \\
\text { elimination of obstacles }\end{array}$ & $\begin{array}{l}\text { - Tightly assigned resources vs. slack resources } \\
\text { - Individual task focus vs. support of shared work }\end{array}$ \\
\hline $\begin{array}{l}\text { Interacting } \\
\text { socially }\end{array}$ & $\begin{array}{l}\text { Social cohesion, loyalty, social } \\
\text { capital, social intelligence, } \\
\text { degree of engagement, role } \\
\text { conflicts }\end{array}$ & $\begin{array}{l}\text { - Appropriate cooperation vs. groupthink } \\
\text { - Individuality vs. group identity } \\
\text { - Maintaining work relationships vs. absorbing time } \\
\text { and interfering with work }\end{array}$ \\
\hline $\begin{array}{l}\text { Providing } \\
\text { service }\end{array}$ & $\begin{array}{l}\text { Efficiency, effectiveness, } \\
\text { reliability, responsiveness, } \\
\text { cost, convenience }\end{array}$ & $\begin{array}{l}\text { - Ease of production vs. customer satisfaction } \\
\text { - Relationship-based vs. transaction-based } \\
\text { - Produced vs. co-produced } \\
\end{array}$ \\
\hline Creating value & $\begin{array}{l}\text { Efficiency, effectiveness, } \\
\text { reliability, responsiveness, } \\
\text { cost, convenience }\end{array}$ & $\begin{array}{l}\text { - Value for provider vs. value for customer } \\
\text { - Cost to provider vs. cost to customer or society } \\
\text { - Produce and transfer vs. work together }\end{array}$ \\
\hline $\begin{array}{l}\text { Maintaining } \\
\text { security }\end{array}$ & $\begin{array}{l}\text { Number of incidents, } \\
\text { Extent of losses }\end{array}$ & $\begin{array}{l}\text { - Attention to security vs. attention to work } \\
\text { - Restrictions vs. ability to satisfy customers }\end{array}$ \\
\hline
\end{tabular}

Common Sub-facets. Table A5 illustrates how most facets bring sub-facets that are often useful when exploring a facet of work in depth. As with facets, sub-facets are activities or groups of activities. Thus, people discussing the facet making decisions might start by identifying and discussing consequential decisions in the relevant situation. They might build on that by looking at sub-facets, i.e., focusing on how 
problems are defined, how criteria are identified, how relevant information is gathered, and so on. That type of attention to specific facets and sub-facets usually is not included in typical descriptions of SA\&D, BPM, and EM. Similarly, attention to these topics is not usually included in guidelines about how to perform case study research or action research that tries to understand a business situation.

Table A5. Sub-facets related to each facet

\begin{tabular}{|c|c|}
\hline Facet & Related sub-facets \\
\hline $\begin{array}{l}\text { Making } \\
\text { decisions }\end{array}$ & $\begin{array}{l}\text { Defining the problem; identifying criteria for making the decision; gathering relevant } \\
\text { information; analyzing the information; defining alternatives; selecting among } \\
\text { alternatives; explaining the decision to stakeholders. }\end{array}$ \\
\hline Communicating & $\begin{array}{l}\text { Formulating the message; encoding the message, conveying the message; receiving } \\
\text { the message; decoding the message; verifying that the message was received and } \\
\text { understood. }\end{array}$ \\
\hline $\begin{array}{l}\text { Providing } \\
\text { information }\end{array}$ & $\begin{array}{l}\text { Identifying alternative ways to provide information that might be needed; identifying } \\
\text { the most appropriate way to provide required information; packaging information for } \\
\text { conveyance to the user; transmitting and/or displaying the information. }\end{array}$ \\
\hline $\begin{array}{l}\text { Representing } \\
\text { reality }\end{array}$ & $\begin{array}{l}\text { Identifying key aspects of reality that matter in the situation at hand; identifying ways } \\
\text { to represent those aspects of reality; selecting the most acceptable representation in } \\
\text { terms of usefulness versus cost; capturing and manipulating whatever information is } \\
\text { needed to produce the desired representation of reality. }\end{array}$ \\
\hline $\begin{array}{l}\text { Applying } \\
\text { knowledge }\end{array}$ & $\begin{array}{l}\text { Determining the domain; collecting relevant data, if any; distilling data into } \\
\text { knowledge; identify relevant knowledge; apply knowledge to the situation }\end{array}$ \\
\hline Thinking & $\begin{array}{l}\text { Identifying the topic, visualizing the situation; identifying issues or concerns; } \\
\text { considering knowledge or evidence; considering alternatives; iterating }\end{array}$ \\
\hline Learning & $\begin{array}{l}\text { Determining learning goal; determining learning strategy; recognizing content to be } \\
\text { learned; engaging with content; practicing, receiving feedback; demonstrating } \\
\text { mastery; recognizing limits of understanding }\end{array}$ \\
\hline Planning & $\begin{array}{l}\text { Identifying scope and timeline; identifying objectives; identifying relevant resources; } \\
\text { producing a plan; evaluating feasibility, likely goal attainment, and risks for a possible } \\
\text { plan; iterating }\end{array}$ \\
\hline $\begin{array}{l}\text { Controlling } \\
\text { execution }\end{array}$ & $\begin{array}{l}\text { Identifying control points and goals; collecting information related to the degree of } \\
\text { goal achievement; using the information to stay on track }\end{array}$ \\
\hline Coordinating & $\begin{array}{l}\text { Identifying dependencies; deciding on methods for addressing dependencies; } \\
\text { executing coordination mechanisms; monitoring coordination effectiveness }\end{array}$ \\
\hline Improvising & $\begin{array}{l}\text { Identifying goals of improvisation; deciding how to start improvisation; initiating } \\
\text { improvisation; monitoring progress of the improvisation; deciding how to proceed }\end{array}$ \\
\hline $\begin{array}{l}\text { Processing } \\
\text { information }\end{array}$ & $\begin{array}{l}\text { Capturing information; transmitting information; storing information; retrieving } \\
\text { information; deleting information; manipulating information; displaying information. }\end{array}$ \\
\hline $\begin{array}{l}\text { Performing } \\
\text { physical work }\end{array}$ & $\begin{array}{l}\text { Grasping; moving, lifting, pushing; pulling; transporting; combining, transforming; } \\
\text { sorting; filtering; mixing, constructing; cleaning }\end{array}$ \\
\hline $\begin{array}{l}\text { Performing } \\
\text { support work }\end{array}$ & $\begin{array}{l}\text { Identifying transient obstacles; deciding how to help; obtaining needed resources; } \\
\text { providing resources; performing improvised tasks }\end{array}$ \\
\hline $\begin{array}{l}\text { Interacting } \\
\text { socially }\end{array}$ & $\begin{array}{l}\text { Communicating; welcoming; initiating conversations; establishing relationships; } \\
\text { creating social capital; resolving conflicts; maintaining loyalty }\end{array}$ \\
\hline $\begin{array}{l}\text { Providing } \\
\text { service }\end{array}$ & $\begin{array}{l}\text { Identifying beneficiaries; determining beneficiary needs; identifying ways to serve } \\
\text { beneficiaries; executing service activities; monitoring service activities; monitoring } \\
\text { benefits for customers }\end{array}$ \\
\hline Creating value & $\begin{array}{l}\text { Defining relevant aspects of value; deciding how to create value; performing activities } \\
\text { that add or deliver value; monitoring whether value is captured; monitoring to assure } \\
\text { providers and customers both benefit }\end{array}$ \\
\hline $\begin{array}{l}\text { Maintaining } \\
\text { security }\end{array}$ & $\begin{array}{l}\text { Identifying security goals; identifying threats and risks; defining countermeasures } \\
\text { against threats; training staff; executing countermeasures }\end{array}$ \\
\hline
\end{tabular}

Bringing facets of work into systems analysis. The various facets of work can be applied in systems analysis checklists or analysis tools for exploring issues beyond the content of use cases, activity diagrams, 
and typical summaries of problems, processes, information, and constraints. Table A6 shows a starting point for that type of tool. The tools or checklists could provide typical open-ended questions and follow-on questions supporting consideration of the scope and content of each facet of work within the situation.

The questions in Table A6 are straightforward and can be pursued without deep theoretical knowledge in each area. Many surely are pursued in some way in some current systems analysis efforts. Using something like Table A6 might reduce the likelihood of overlooking many important issues. A possible application in research takes the form of checklists for identifying types of issues that were pursued or ignored in real world settings.

Pre-specified templates or interactive tools related to theoretical concepts in each area might go much further. For example, relevant questions for making decisions might use concepts such as utility, risk tolerance, and local vs. global optimality.

Table A6. Open-ended questions related to different facets of work

\begin{tabular}{|c|c|}
\hline Facet & Open-ended questions for starting a discussion, plus follow-on questions \\
\hline $\begin{array}{l}\text { Making } \\
\text { decisions }\end{array}$ & $\begin{array}{l}\text { Open-ended question: How do the available methods and information help in making } \\
\text { important decisions? } \\
\text {. Follow-on questions: What decisions are made with incomplete, inaccurate, or } \\
\text { outdated methods or information? How might better methods or information help in } \\
\text { making decisions? Where would that information come from? }\end{array}$ \\
\hline Communicating & $\begin{array}{l}\text { Open-ended question: In what ways is communication effective or ineffective in this } \\
\text { situation? } \\
\text {... Follow-on questions: Where and how does ineffective communication degrade } \\
\text { performance or cause problems interpersonal issues? Where is information garbled } \\
\text { in communication? Where does inadequate communication of information between } \\
\text { locations cause problems? }\end{array}$ \\
\hline $\begin{array}{l}\text { Providing } \\
\text { information }\end{array}$ & $\begin{array}{l}\text { Open-ended question: How does the available information succeed or fail in helping } \\
\text { managers understand what is going on? } \\
\text {... Follow-on questions: How do managers figure out what is going on? Through } \\
\text { standard information systems? Through spreadsheets? Through face-to-face } \\
\text { discussions? What important information is unavailable? What important information } \\
\text { is missing or difficult to obtain? }\end{array}$ \\
\hline $\begin{array}{l}\text { Representing } \\
\text { reality }\end{array}$ & $\begin{array}{l}\text { Open-ended question: What are examples of important information that does not } \\
\text { exist in available information systems or is not represented well? } \\
\text {... Follow-on questions: Is information recorded or presented in a way that requires } \\
\text { manual workarounds to figure out what is going on? Is the information from official } \\
\text { or corporate information sources as accurate or timely as information from local } \\
\text { spreadsheets? What is the impact of shortcomings related to how available } \\
\text { information represents reality? }\end{array}$ \\
\hline $\begin{array}{l}\text { Applying } \\
\text { knowledge }\end{array}$ & $\begin{array}{l}\text { Open-ended question: To what extent is it necessary to use explicit knowledge that } \\
\text { is codified and computerized? } \\
\text {... Follow-on questions: In what ways is the knowledge and intuition of people in the } \\
\text { setting inadequate for the purposes at hand? What data might be used in a } \\
\text { computerized approach to compiling and formalizing the knowledge? In what ways } \\
\text { could that data have biases that would skew the results of decisions? What are the } \\
\text { knowledge-related limitations of current or proposed information systems? }\end{array}$ \\
\hline Thinking & $\begin{array}{l}\text { Open-ended question: Are there situations where people seem not to have enough } \\
\text { time or liberty to think carefully about what needs to be done? } \\
\text {... Follow-on questions: Does performance pressure or attention to minute details } \\
\text { drive out the ability to think about important issues? Are people frustrated about how } \\
\text { the work environment affects their ability to think creatively? Do people feel that they } \\
\text { lack opportunities to think through problems with the help of their colleagues? }\end{array}$ \\
\hline Learning & $\begin{array}{l}\text { Open-ended question: In what ways is learning important for successfully performing } \\
\text { responsibilities in this situation? } \\
\ldots \text { Follow-on questions: What learning occurs before this activity or system is } \\
\text { considered operational? What learning occurs during operation and through } \\
\text { feedback? How is that learning supervised? }\end{array}$ \\
\hline
\end{tabular}




\begin{tabular}{|c|c|}
\hline Planning & $\begin{array}{l}\text { Open-ended question: How effective are planning processes in this setting? } \\
\text { … Follow-on questions: Are plans taken seriously in this setting? What happens when } \\
\text { it becomes apparent that current plans will not be achieved? How well do plans } \\
\text { consider risks and uncertainties about what needs to be accomplished and what is } \\
\text { feasible to accomplish? }\end{array}$ \\
\hline $\begin{array}{l}\text { Controlling } \\
\text { execution }\end{array}$ & $\begin{array}{l}\text { Open-ended question: How well do existing methods and information help the } \\
\text { organization meet its short-term and long-term targets? } \\
\ldots \text { Follow-on questions: Is information related to controlling execution ever inaccurate } \\
\text { or misleading enough that it causes management or execution errors? What changes } \\
\text { in existing methods and information would help the organization control execution } \\
\text { more effectively? }\end{array}$ \\
\hline Coordinating & $\begin{array}{l}\text { Open-ended question: Describe any common situations where coordination between } \\
\text { people or departments is challenging. } \\
\text {.. Follow-on questions: What kinds of dependencies lead to coordination challenges? } \\
\text { What kinds of methods are used to establish and maintain coordination? In what } \\
\text { ways is coordination monitored or rewarded? }\end{array}$ \\
\hline Improvising & $\begin{array}{l}\text { Open-ended question: What kinds of situations occur where it is necessary to } \\
\text { improvise in the short term based on whatever resources are available? } \\
\text {... Follow-on questions: Describe any common situations where noncompliance with } \\
\text { established practices is necessary in order to complete work or meet customer } \\
\text { needs. Describe the extent to which management supports improvisation that seems } \\
\text { appropriate to the people who are doing the work. }\end{array}$ \\
\hline $\begin{array}{l}\text { Processing } \\
\text { information }\end{array}$ & $\begin{array}{l}\text { Open-ended question: Are there situations in which capturing, transmitting, storing, } \\
\text { retrieving, deleting, displaying, or manipulating important information is ineffective, } \\
\text { error-prone, or costly in time and effort? } \\
\text {... Follow-on questions: What information is captured or transmitted inaccurately? } \\
\text { What information is difficult to store or retrieve? What information would be more } \\
\text { useful if it could be refined further through calculations or visual display? }\end{array}$ \\
\hline $\begin{array}{l}\text { Performing } \\
\text { physical work }\end{array}$ & $\begin{array}{l}\text { Open-ended question: What kinds of physical work are important in this situation? } \\
\text { … Follow-on questions: Are there any significant challenges in performing that } \\
\text { physical work? Are there ways in which better processing of information might } \\
\text { replace or facilitate some of that physical work? }\end{array}$ \\
\hline $\begin{array}{l}\text { Performing } \\
\text { support work }\end{array}$ & $\begin{array}{l}\text { Open-ended question: Is any of the recognized work in the situation related to helping } \\
\text { other people perform their work? } \\
\ldots \text { Follow-on questions: Do people have assistants whose job is to help them perform } \\
\text { their work? In what ways do people in this work situation help each other by } \\
\text { eliminating minor obstacles, sharing time and other resources, and making sure that } \\
\text { everyone succeeds in doing their work in a timely and convenient way? }\end{array}$ \\
\hline $\begin{array}{l}\text { Interacting } \\
\text { socially }\end{array}$ & $\begin{array}{l}\text { Open-ended question: In what ways is social interaction important in this work } \\
\text { setting? } \\
\text {... Follow-on questions: Are social interactions viewed as important in this setting? } \\
\text { Does social interaction present any significant challenges in this setting? Are there } \\
\text { ways in which work methods or availability of information have negative effects on } \\
\text { social interactions? What are possible ways to strengthen social relationships and } \\
\text { cooperation? }\end{array}$ \\
\hline $\begin{array}{l}\text { Providing } \\
\text { service }\end{array}$ & $\begin{array}{l}\text { Open-ended question: How do the available methods, information, and other } \\
\text { resources help people perform service for internal or external customers? } \\
\text {... Follow-on questions: Is information readily available about what customers really } \\
\text { want or need? How well do customers take responsibility for indicating what they } \\
\text { want? How good is the balance between what the customer sees during service } \\
\text { provision versus what only the provider sees? }\end{array}$ \\
\hline Creating value & $\begin{array}{l}\text { Open-ended question: What do the customers of this work perceive as the most } \\
\text { important aspects of the value that they receive? } \\
\text {... Follow-on questions: How do providers obtain information about whether } \\
\text { customers are receiving what they want or need? Are there important tradeoffs } \\
\text { between providing value for customers and meeting internal goals related to costs, } \\
\text { efficiency, employee satisfaction, and other internal concerns? }\end{array}$ \\
\hline
\end{tabular}




\begin{tabular}{|l|l|}
\hline $\begin{array}{l}\text { Maintaining } \\
\text { security }\end{array}$ & $\begin{array}{l}\text { Open-ended question: What important security-related threats exist or could emerge } \\
\text { in this situation? } \\
\ldots \text { Follow-on questions: Are the threats internal or external? Are the threats related } \\
\text { to awareness of security issues? What security related training has occurred? To } \\
\text { what extent was that training taken seriously? }\end{array}$ \\
\hline
\end{tabular}

\begin{abstract}
About the Authors
Steven Alter is Professor Emeritus at the University of San Francisco. He served as vice president of a manufacturing software start-up that was acquired by Applied Materials. Upon returning to academia he wrote four editions of a major IS textbook. That effort led to research focused on developing systems analysis and design methods that business professionals could use for their own understanding and to help them collaborate more effectively with IT professionals, consultants, and vendors. The result was various versions of the -work system method (WSM), which focuses on the business problem of creating or improving a sociotechnical work system, rather than the more limited technical challenge of creating or improving software that satisfies requirements. Most of his articles in journals and conference proceedings are related to articulating and applying the work system perspective, which includes WSM, work system theory (WST), service systems, and extensions of WST such as a theory of workarounds and a service value chain framework.
\end{abstract}

Copyright ( $~ 2021$ by the Association for Information Systems. Permission to make digital or hard copies of all or part of this work for personal or classroom use is granted without fee provided that copies are not made or distributed for profit or commercial advantage and that copies bear this notice and full citation on the first page. Copyright for components of this work owned by others than the Association for Information Systems must be honored. Abstracting with credit is permitted. To copy otherwise, to republish, to post on servers, or to redistribute to lists requires prior specific permission and/or fee. Request permission to publish from: AIS Administrative Office, P.O. Box 2712 Atlanta, GA, 30301-2712 Attn: Reprints are via e-mail from publications@aisnet.org. 